\title{
COMPARATIVE STUDY OF TYPE-MORPHOLOGY ARCHITECTURE BOROBUDUR-PRAMBANAN TEMPLE OF ANGKOR WAT \\ CASE STUDY ON MASS PROCESSES, LOOKS, SOCKS, AND ORNAMENTS
}

\author{
${ }^{1}$ Andreas Martinus. ${ }^{2}$ Dr. Rahadhian Prajudi Herwindo, ST., MT. \\ ${ }^{I}$ Student in the Bachelor's (S-1) Study Program in Architecture \\ at Parahyangan Catholic University \\ ${ }^{2}$ Senior lecturer in the Bachelor's (S-1) Study Program in Architecture \\ at Parahyangan Catholic University
}

\begin{abstract}
There are allegations that elements of Javanese temples are also can be found at The Angkorian temples because the Java Middle Classic temples are older than Angkorian temples and Jayawarman II lived in Java at that time. This can be proved by a comparative process between the architecture elements: mass, plans, figures and ornaments owned by the temples that represents its era in both kingdom. Angkor Wat is a synthesis of the development in Angkor culture that reach its the peak of glory. Angkor Wat has architectural elements of Java Middle Classic temples, especially Prambanan and Borobudur. This led to the alleged of similarity from architectural elements between the temples in the two kingdoms.

This Study approached by quantitative with semi qualitative method. Through the study on the main temple buildings of the Java Middle Classic and the main temples of the Angkor Wat era with purposive sampling in relation of mass, plan, figure, and ornament. Described descriptively.

Angkor Wat is generally inspired by Borobudur-Prambanan. Broadly speaking, it shows the similarity of Prambanan-Borobudur architectural elements to Angkor Wat. Angkor Wat is a synthesis of combining the elements (eclecticism) of Borobudur-Prambanan, but Prambanan has stronger element (indoor temple, tower temple, Hindu temple). In principle (mass, plan, and figure) shows the incorporation of Borobudur-Prambanan, but by ornament on its processing indicates there is further development (dominated findings exist but not similar).
\end{abstract}

Key Words: tipo-morphology, comparison, Angkor, Indochina, Java

\section{STUDI KOMPARASI TIPO-MORFOLOGI ARSITEKTUR CANDI BOROBUDUR-PRAMBANAN TERHADAP ANGKOR WAT KAJIAN PADA TATA MASSA, DENAH, SOSOK, DAN ORNAMEN}

\author{
${ }^{1}$ Andreas Martinus. ${ }^{2}$ Dr. Rahadhian Prajudi Herwindo, ST., MT. \\ ${ }^{1}$ Mahasiswa S1 Program Studi Arsitektur Universitas Katolik Parahyangan \\ ${ }^{2}$ Dosen Pembimbing S1 Program Studi Arsitektur Universitas Katolik Parahyangan
}

\begin{abstract}
Abstrak- Terdapat dugaan bahwa unsur-unsur candi Jawa didapatkan juga pada candi-candi di Angkor, hal ini dikarenakan candi Jawa Klasik Tengah lebih tua dibandingkan Angkor dan Jayawarman II penah tinggal di Jawa pada masa itu. Hal ini terbukti dengan cara sebuah proses komparasi antara unsur-unsur arsitektur: tata massa, denah, sosok dan ornamen yang dimiliki oleh candi yang mewakili zamannya pada kedua kerajaan tersebut. Angkor Wat merupakan sintesis perkembangan kebudayaan Angkor sampai dengan mencapai puncak kejayaan.
\end{abstract}

${ }^{1}$ Corresponding Author: pandamartinus@gmail.com 
Angkor Wat memiliki unsur arsitektur candi Jawa Klasik Tengah khususnya Prambanan dan Borobudur. Hal ini memunculkan dugaan kemiripan unsur arsitektur diantara candi di dua kerajaan.

Studi ini dilakukan dengan metode Kualitatif semi Kuantitatif. Melalui pengkajian pada bangunanbangunan candi utama era Klasik Tengah Jawa dan candi utama era Angkor Wat dengan purposive sampling dalam hubungannya dengan tata massa, denah, sosok, dan ornamen. Dijabarkan secara deskriptif-analitik.

Secara umum Angkor Wat terinspirasi Borobudur-Prambanan. Secara garis besar menunjukan adanya persamaan unsur arsitektur Prambanan-Borobudur terhadap Angkor Wat. Angkor Wat merupakan sintesa penggabungan unsur (eklektisism) Borobudur-Prambanan, namun unsur Prambanan lebih kuat (candi beruang, candi menara, candi Hindu). Secara prinsip (tata massa, denah, dan sosok) menunjukkan penggabungan Borobudur-Prambanan, namun secara ornamen pada pengolahannya menunjukkan ada pengembangan lebih lanjut (didominasi temuan ada tapi tidak serupa).

Kata Kunci: tipo-morfologi, komparasi, Angkor, Indocina, Jawa

\section{PENDAHULUAN}

Angkor Wat dibangun pada masa puncak kejayaan Angkor karena merupakan representasi puncak kejayaan candi di Kamboja, sama seperti Borobudur dan Prambanan sebagai representasi puncak kejayaan candi di Indonesia, dengan demikian candi dari dua kerjaan berbeda tersebut dapat dikatakan memiliki kesetaraan untuk dibandingkan karena sama-sama berperan sebagai candi ultimate. Candi Borobudur dan Prambanan dibangun berdasarkan konsep lokal genius Indonesia karena tidak ada yang seperti BorobudurPrambanan pada zaman itu. Jayawarman II, raja pendiri Angkor, pernah tinggal di Pulau Jawa ketika Borobudur sedang dibangunyang memungkinkan terjadinya trasfer pengetahuan ke Angkor. Angkor Wat dibangun pada era setelah selesainya pembangunan Candi Borobudur dan Prambanan.

Dari jabaran beberapa premis tersebut memunculkan dugaan bahwa unsur-unsur candi Jawa didapatkan juga pada candi-candi di Angkor, hal ini dikarenakan candi Jawa Klasik Tengah lebih tua dibandingkan Angkor dan Jayawarman II penah tinggal di Jawa pada masa itu. Hal ini terbukti dengan cara sebuah proses komparasi antara unsur-unsur arsitektur: tata massa, denah, sosok dan ornamen yang dimiliki oleh candi yang mewakili zamannya pada kedua kerajaan tersebut. Hal ini memunculkan pertanyaan dari penelitian: Bagaimana persamaan dan perbedaan (komparasi) arsitektur (tata massa, denah, sosok, dan ornamen) Candi Borobudur dan Candi Prambanan terhadap Candi Angkor Wat?

\section{KAJIAN TEORI}

Borobudur didirikan di atas dan di sekitar lereng sebuah bukit berbentuk punden berundak yang berbeda dengan bangunan suci lainnya. Bangunan Borobudur pada hakekatnya bangunan stupa, namun tidak sebagaimana lazimnya stupa yang berbentuk kubah, tetapi merupakan punden berundak dengan 6 tingkat berbentuk bujur sangkar, tiga tingkat berbentuk bundar melingkar dan sebuah stupa induk sebagai puncaknya. Semua bagian itu merupakan satu kesatuan dan secara keseluruhan merupakan bangunan satu stupa.

Prambanan diperkirakan dibangun pada akhir abad ke-9. Hal ini berdasarkan keterangan yang terdapat di dalam prasasti Siwa Graha yang ditemukan tidak jauh dari kompleks ini. Isi prasasti itu menyatakan mengenai suatu pembangunan kuil yang dinamakan Siwagraha. Keadaan yang diceritakan sesuai benar dengan keadaan Candi Prambanan itu sendiri. Pada bagian ke dua prasasti ini dinyatakan tentang peresmian kuil Siwa Graha yang tidak lain adalah candi Prambanan pada hari Kamis Wage tanggal 11 bulan Margasirsa tahun 778 Saka atau jatuh pada 11 November $856 \mathrm{M}$. 
Angkor Wat dibangun pada abad ke $12 \mathrm{M}$. Angkor memulai masa kejayaanya dengan terebutnya Angkor oleh dinasti yang baru yaitu Dinasti Surya. Dengan kepemimpinan Raja Suryawarman, seluruh masyarakat Angkor menata segala penemuanya dan menyatukanya menjadi sesuatu yang sempurna dan serasi. Demikianlah maka peradaban Khemer yang berkembang sejak tiga abad lamanya mencapai puncaknya dengan dibangunya Angkor Wat, simbol universal kerajaan Khemer. Dengan konstruksi batunya, Angkor Wat dapat merangkum peradaban Khemer.

\section{METODA PENELITIAN}

Penelitian ini memiliki tujuan utama untuk mencari pengaruh yang diberikan oleh candi Jawa Era Klasik Tengah pada Angkor Wat yang merupakan puncak kejayaan Kerajaan Angkor. Namun karena disadari bahwa penulis memiliki keterbatasan waktu maka penulis membagibagi penelitian besar tersebut menjadi beberapa segmen penelitian. Maka pada segmen penelitian ini topik yang diangkat adalah komparasi unsur arsitektur yang dimiliki oleh objek penelitian. Pada penelitian dengan topik studi komparasi ini juga memiliki keterbatasan yaitu tidak semua lokasi dapat dijangkau melalui survey lapangan karena keterbatasan biaya dan waktu, maka dari itu akan dipilih secara purposive sampling. Untuk mengkontribusi kekurangan yang dimiliki oleh penelitian ini, akan dibantu pula melalui studi literatur dan internet.

Pengkajian dan perbandingan akan dilakukan pada tata massa, denah, sosok, dan ornamen dari arsitektur Candi Jawa Era Klasik Tengah terhadap Gaya Angkor Wat. Kemudian yang dipilih sebagai contoh adalah bangunan yang dianggap dapat mewakili zamannya (candi utama/ultimate) untuk menjelaskan persamaan dan perbedaan yang dimiliki oleh masingmasing unsur arsitektur. Untuk pendekatan pada penelitian ini dilakukan dengan metode Kualitatif. Secara kualitatif melalui pengkajian pada bangunan-bangunan candi utama era Klasik Tengah dan candi utama pada era Angkor Wat dengan purposive sampling dalam hubungannya dengan tata massa, denah, sosok, dan ornamen. Penelitian ini dilakukan secara deskriptif-analitik di mana dalam konteks deskriptif digunakan untuk menjelaskan unsur arsitektur bangunan masa Klasik Tengah tersebut secara holistic dan bagaimana komparasinya terhadap gaya arsitektur Angkor Wat. Sedangkan analitik digunakan dalam menunjukkan identifikasi komparasi unsur arsitektur Candi Jawa Klasik Tengah terhadap Angkor Wat.

Analisis data dilakukan dengan mengkomparasi hasil observasi terhadap elemen dan unsur-unsur arsitektur pada masing-masing candi, kemudian dihubungkan dan dibandingkan dengan teori-teori dari studi literatur yang berkaitan dengan judul penelitian. Penyertaan hasil gambar dokumentasi dari observasi juga diikutsetakan untuk memperkuat analisa yang dilakukan. Dari tiap unsur arsitektur yang dimiliki tiap candi akan dibandingan dengan cara mencari persamaan dan perbedaannya. Untuk dapat melakukan hal tersebut maka yang menjadi tolok ukur pembanding adalah teori unsur candi dengan beberapa aspek pembanding di dalamnya. Penilaian terhadap perbandingan unsur arsitektur di bagi menjadi tiga: serupa, tidak serupa (ada), dan tidak ada. Tidak Ada artinya tidak terdapat elemen pada candi rujukan terhadap candi objek studi yang dapat dibandingkan baik secara jenis, fungsi maupun rupa. Tidak serupa artinya terdapat elemen pada candi rujukan terhadap candi objek studi yang dapat dibandingkan baik secara jenis maupun fungsi dengan rupa berbeda. Serupa artinya terdapat elemen pada candi rujukan terhadap candi objek studi yang dapat dibandingkan baik secara jenis maupun fungsi dengan rupa sama. Setelah melalui proses perbandingan dengan mencari persamaan dan perbedaan unsur arsitektur yang dimiliki maka dapat diketahui hasil analisis komparasi yang setelahnya dapat ditarik kesimpulan melalui hasil tersebut. 


\section{ANALISA}

\subsection{KOMPARASI UNSUR ARSITEKTUR TERHADAP ANGKOR WAT}

Berdasarkan data dan pemaparan candi yang menjadi rujukan (Borobudur dan Prambanan) dan candi yang menjadi objek studi (Angkor Wat) maka dapat dilakukan analisis di antara keduanya untuk bisa melakukan studi komparasi dengan menemukan persamaan dan perbedaan unsur arsitektur candi rujukan pada candi objek studi. Komparasi tersebut dilakukan dengan cara memaparkan karakteristik yang dimiliki oleh tiap candi berdasarkan tolok ukur unsur arsitektur candi: tata massa, denah, sosok, dan ornamen. Pemaparan karakteristik setiap candi juga akan dibahas melalui aspek-aspek yang dimiliki oleh tiap unsur arsitektur tersebut. Kemudian dari paparan tersebut akan dicari persamaan dan perbedaan yang dimiliki oleh candi rujukan terhadap candi objek studi.

\subsubsection{KOMPARASI TATA MASSA}

Komparasi unsur arsitektur candi pada konteks tata massa akan dipaparkan melalui beberapa aspek yang dimiliki oleh unsur ini berdasarkan teori.

Tabel 1. Komparasi Unsur Arsitektur Tata Massa Borobudur dan Prambanan terhadap Angkor Wat Sumber gambar: Pusat Studi Angkor, Balai Penelitian Borobudur, dan Balai Pemugaran Cagar Budaya Yogyakarta; dengan modifikasi penulis

\begin{tabular}{|c|c|c|}
\hline \multicolumn{2}{|c|}{ Candi Rujukan } & Objek Candi \\
\hline Borobudur & Prambanan & Angkor Wat \\
\hline 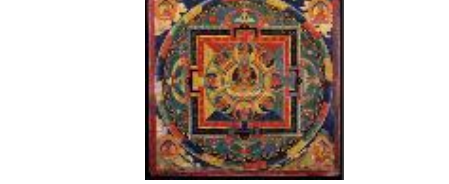 & $=$ & $=$ \\
\hline $\begin{array}{l}\text { Penerapan Mandala } \\
\text { Mandala Budha }\end{array}$ & $\begin{array}{l}\text { Penerapan Bentuk Denah } \\
\text { Mandala Hindu }\end{array}$ & $\begin{array}{l}\text { Penerapan Bentuk Denah } \\
\text { Mandala Hindu }\end{array}$ \\
\hline 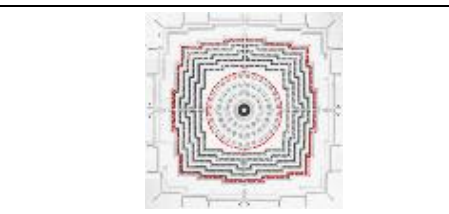 & $\mid \begin{array}{l}0^{\circ} a \\
0 \\
0, a\end{array}$ & \\
\hline $\begin{array}{l}\text { Bentuk Dasar Tapak } \\
\text { Cruciform dengan banyak siku } \\
\text { pada sisi sisinya. Memiliki } \\
\text { bentuk dasar dengan } \\
\text { kecenderungan persegi }\end{array}$ & $\begin{array}{l}\text { Bentuk Dasar Tapak } \\
\text { Cruciform dengan siku-siku } \\
\text { berjumlah dua buah pada } \\
\text { sudutnya dan memiliki } \\
\text { kecenderungan bentuk dasar } \\
\text { persegi }\end{array}$ & $\begin{array}{l}\text { Bentuk Dasar Tapak } \\
\text { Persegi panjang, memiliki banyak } \\
\text { siku dengan ukuran kecil pada sudut } \\
\text { dan tengah sisi (bentuk cursiform } \\
\text { muncul pada detail) }\end{array}$ \\
\hline $\begin{array}{l}\text { Penggabungan Geometri tapak } \\
\text { Tatanan dinding luar persegi, } \\
\text { tatanan dalam berbentuk } \\
\text { lingkaran }\end{array}$ & $\begin{array}{l}\text { Penggabungan Geometri } \\
\text { tapak } \\
\text { Tatanan Didinding luar } \\
\text { Cruciform, Tatanan dinding } \\
\text { dalam persegi }\end{array}$ & $\begin{array}{l}\text { Penggabungan Geometri tapak } \\
\text { terluar berbentuk persegi panjang, } \\
\text { Tatanan dinding dalam adalah } \\
\text { persegi }\end{array}$ \\
\hline Bentuk Dasar Tapak & Bentuk Dasar Tapak & Bentuk Dasar Tapak \\
\hline
\end{tabular}




\begin{tabular}{|c|c|c|}
\hline \multicolumn{2}{|c|}{ Candi Rujukan } & Objek Candi \\
\hline Borobudur & Prambanan & Angkor Wat \\
\hline $\begin{array}{l}\text { Cruciform dengan banyak siku } \\
\text { pada sisi sisinya. Memiliki } \\
\text { bentuk dasar dengan } \\
\text { kecenderungan persegi }\end{array}$ & $\begin{array}{l}\text { Cruciform dengan siku-siku } \\
\text { berjumlah dua buah pada } \\
\text { sudutnya dan memiliki } \\
\text { kecenderungan bentuk dasar } \\
\text { persegi }\end{array}$ & $\begin{array}{l}\text { Persegi panjang, memiliki banyak } \\
\text { siku dengan ukuran kecil pada sudut } \\
\text { dan tengah sisi (bentuk cursiform } \\
\text { muncul pada detail) }\end{array}$ \\
\hline $\begin{array}{l}\text { Penggabungan Geometri tapak } \\
\text { Tatanan dinding luar persegi, } \\
\text { tatanan dalam berbentuk } \\
\text { lingkaran }\end{array}$ & $\begin{array}{l}\text { Penggabungan Geometri } \\
\text { tapak } \\
\text { Tatanan Didinding luar } \\
\text { Cruciform, Tatanan dinding } \\
\text { dalam persegi }\end{array}$ & $\begin{array}{l}\text { Penggabungan Geometri tapak } \\
\text { terluar berbentuk persegi panjang, } \\
\text { Tatanan dinding dalam adalah } \\
\text { persegi }\end{array}$ \\
\hline $\begin{array}{l}\text { Hirarki dibaca melalui undakan } \\
\text { dan gerbang } \\
3 \text { buah hirarki (Khamadatu, } \\
\text { Rupadatu, Arupadatu). }\end{array}$ & $\begin{array}{l}\text { Hirarki pada Tapak dibaca } \\
\text { melalui undakan \& gerbang } \\
3 \text { buah hirarki (pagar terluar, } \\
\text { Pagar perwara, dan candi } \\
\text { utama). }\end{array}$ & $\begin{array}{l}\text { Hirarki pada Tapak dibaca melalui } \\
\text { undakan \& gerbang } \\
3 \text { buah (galeri luar, galleri atas, } \\
\text { pagoda intan). }\end{array}$ \\
\hline $\begin{array}{l}\text { Hirarki semakin pusat semakin } \\
\text { suci } \\
\text { Candi utama berada tepat di } \\
\text { pusat. }\end{array}$ & $\begin{array}{l}\text { Hirarki semakin pusat } \\
\text { semakin suci } \\
\text { Candi utama tidak berada tepat } \\
\text { di pusat, namun sedikit mundur }\end{array}$ & $\begin{array}{l}\text { Hirarki semakin pusat semakin } \\
\text { suci } \\
\text { Candi utama tidak berada tepat di } \\
\text { pusat. }\end{array}$ \\
\hline 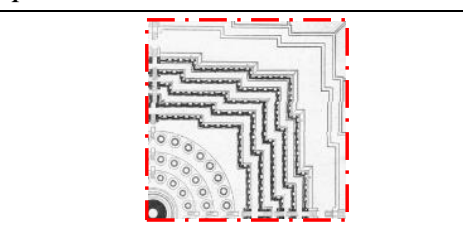 & 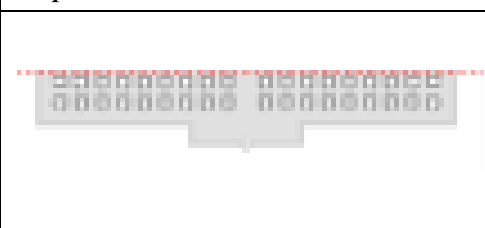 & (2) \\
\hline $\begin{array}{l}\text { Perulangan bentuk dasar } \\
\text { geometric } \\
\text { Dinding/Pagar dan stupa }\end{array}$ & $\begin{array}{l}\text { Perulangan bentuk dasar } \\
\text { geometric } \\
\text { Dibentuk oleh candi perwara }\end{array}$ & $\begin{array}{l}\text { Perulangan bentuk dasar } \\
\text { geometric } \\
\text { Selasar/pagar/galeri dan menara } \\
\text { candi }\end{array}$ \\
\hline $\begin{array}{l}\text { Sisi Simetri } \\
\text { Timur-Barat } \\
\text { Utara-Selatan } \\
\text { Diagonal }\end{array}$ & $\begin{array}{l}\text { Sisi Simetri } \\
\text { Jika dipotong Timur-Barat maka } \\
\text { sisi timur dan barat adalah } \\
\text { simetri }\end{array}$ & $\begin{array}{l}\text { Sisi Simetri } \\
\text { Jika dipotong Timur-Barat maka sisi } \\
\text { utara dan selatan dari keseluruhan } \\
\text { candi adalah simetri, sebaliknya }\end{array}$ \\
\hline $\begin{array}{l}\text { Axis Memusat } \\
\text { Tatanan memusat pada stupa } \\
\text { utama, }\end{array}$ & $\begin{array}{l}\text { Axis Memusat } \\
\text { Tatanan memusat candi perwara } \\
\text { terhadap area candi utama }\end{array}$ & $\begin{array}{l}\text { Axis Memusat } \\
\text { Tatanan memusat berlapis } \\
\text { mengeliling candi utama } \\
\end{array}$ \\
\hline Axis Linier & Axis Linier & Axis Linier \\
\hline
\end{tabular}




\begin{tabular}{|c|c|c|}
\hline \multicolumn{2}{|c|}{ Candi Rujukan } & Objek Candi \\
\hline Borobudur & Prambanan & Angkor Wat \\
\hline $\begin{array}{l}\text { Tatanan linier terhadap Candi } \\
\text { Pawon dan mendut }\end{array}$ & $\begin{array}{l}\text { Tatanan linier pada candi } \\
\text { wahana dan tiga candi utama }\end{array}$ & $\begin{array}{l}\text { Tatanan linier pada keseluruhan } \\
\text { candi ditunjukan dengan bentuk } \\
\text { memanjang dan candi utama tidak di } \\
\text { tengah }\end{array}$ \\
\hline
\end{tabular}

\subsubsection{KOMPARASI DENAH}

Komparasi unsur arsitektur candi pada konteks denah akan dipaparkan melalui beberapa aspek yang dimiliki oleh unsur ini berdasarkan teori.

Tabel 2. Komparasi Unsur Arsitektur Denah Borobudur dan Prambanan terhadap Angkor Wat Sumber gambar: Pusat Studi Angkor, Balai Penelitian Borobudur, dan Balai Pemugaran Cagar Budaya Yogyakarta; dengan modifikasi penulis

\begin{tabular}{|c|c|c|}
\hline \multicolumn{2}{|c|}{ Candi Rujukan } & Objek Candi \\
\hline Borobudur & Prambanan & Angkor Wat \\
\hline 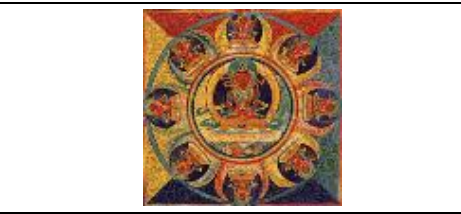 & $\sqrt{5} \frac{7}{n}$ & 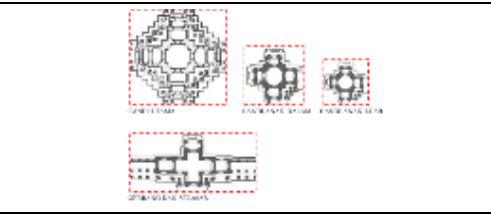 \\
\hline $\begin{array}{l}\text { Penerapan Bentuk Denah } \\
\text { Mewujudkan lingkaran pada } \\
\text { mandala budha }\end{array}$ & $\begin{array}{l}\text { Penerapan Bentuk Denah } \\
\text { Pada candi siwa mewujudkan } \\
\text { bentuk crusiform sebagai } \\
\text { simbolisasi bangunan pemujaan, } \\
\text { pada candi wahana } \\
\text { memperlihatkan bentuk yoni }\end{array}$ & $\begin{array}{l}\text { Penerapan Bentuk Denah } \\
\text { Pada keseluruhan candi (candi } \\
\text { utama, candi anak, gerbang, dan } \\
\text { bentuk tapak mewujudkan bentuk } \\
\text { crusiform sebagai simbolisasi } \\
\text { bangunan pemujaan, } \\
\text { selasar berbentuk linear }\end{array}$ \\
\hline 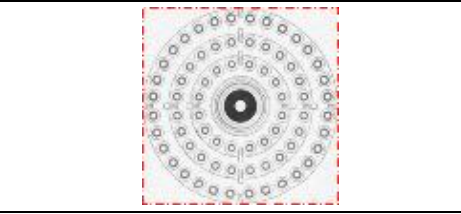 & 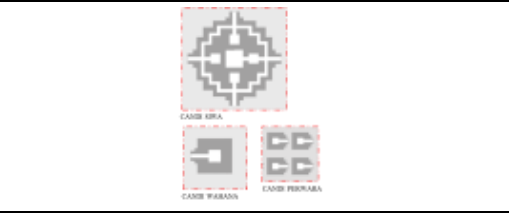 & का \\
\hline $\begin{array}{l}\text { Bentuk Dasar Denah } \\
\text { Bentuk dasar stupa utama } \\
\text { Lingkaran }\end{array}$ & $\begin{array}{l}\text { Bentuk Dasar Denah } \\
\text { Bentuk dasar Candi Utama adalah } \\
\text { cruciform Sedangkan candi } \\
\text { wahana dan perwaranya adalah } \\
\text { persegi }\end{array}$ & $\begin{array}{l}\text { Bentuk Dasar Denah } \\
\text { Bentuk dasar Candi Utama, candi } \\
\text { anak, dan gerbang adalah } \\
\text { cruciform } \\
\text { Sedangkan selasar berbentuk } \\
\text { linier }\end{array}$ \\
\hline $\begin{array}{l}\text { Penggabungan Geometri Denah } \\
\text { Denah stupa dan sekelilingnya } \\
\text { berbentuk lingkaran }\end{array}$ & $\begin{array}{l}\text { Penggabungan Geometri Denah } \\
\text { Pada Candi Utama denah luar } \\
\text { cruciform, denah dalam bujur } \\
\text { sangkar, }\end{array}$ & $\begin{array}{l}\text { Geometri Denah } \\
\text { Pada Candi Utama, candi anak, } \\
\text { dan gerbang, baik bentuk ruang } \\
\text { luar maupun ruang dalamnya } \\
\text { aalah cruciform. }\end{array}$ \\
\hline 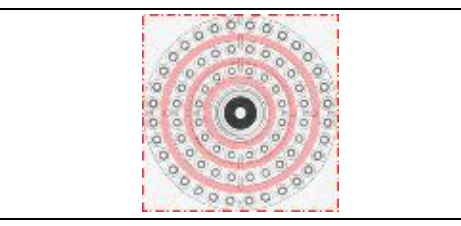 & 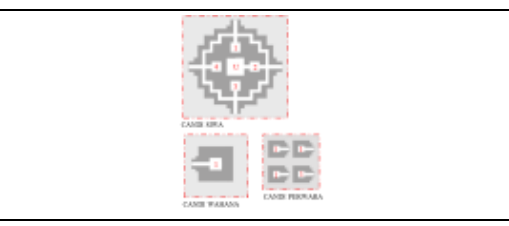 & 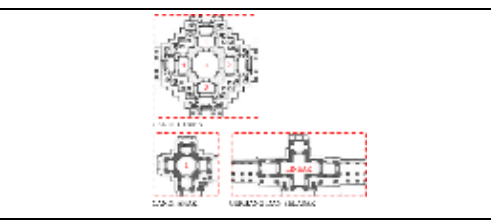 \\
\hline
\end{tabular}




\begin{tabular}{|c|c|c|}
\hline \multicolumn{2}{|c|}{ Candi Rujukan } & Objek Candi \\
\hline Borobudur & Prambanan & Angkor Wat \\
\hline $\begin{array}{l}\text { Area Aktivitas } \\
\text { Seluruh aktivitas berada di luar } \\
\text { stupa, ruang dalam stupa tidak } \\
\text { dapat dieakses }\end{array}$ & $\begin{array}{l}\text { Area Aktivitas } \\
\text { Sebagian besar aktivitas berada di } \\
\text { luar, namun yang paling sakral di } \\
\text { dalam }\end{array}$ & $\begin{array}{l}\text { Area Aktivitas } \\
\text { Sebagian besar aktivitas berada di } \\
\text { luar, namun yang paling sakral di } \\
\text { dalam. }\end{array}$ \\
\hline $\begin{array}{l}\text { Ruang void Candi Utama } \\
\text { Berbentuk lingkaran tanpa } \\
\text { bukaan }\end{array}$ & $\begin{array}{l}\text { Ruang void Candi } \\
\text { Terdapat } 1 \text { ruang utama, dan } 4 \\
\text { ruang di keempat sisinya }\end{array}$ & $\begin{array}{l}\text { Ruang void Candi } \\
\text { Pada candi utama dan candi anak } \\
\text { erdapat } 1 \text { ruang utama, dan } 4 \\
\text { ruang di keempat sisinya. Pada } \\
\text { gerbang dan selasar ruang } \\
\text { berbentuk linear. }\end{array}$ \\
\hline 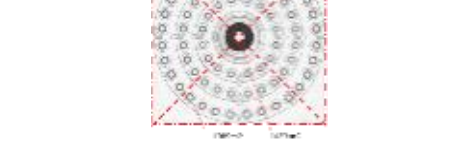 & 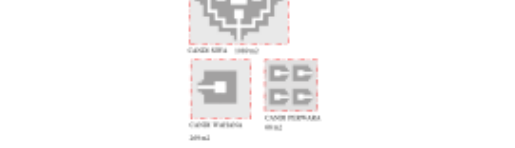 & 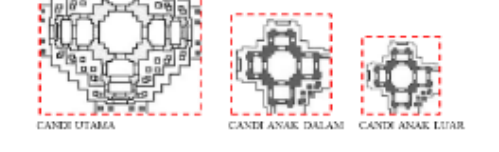 \\
\hline $\begin{array}{l}\text { Pemusatan Hirarki (semakin } \\
\text { pusat semakin suci) }\end{array}$ & $\begin{array}{l}\text { Pemusatan Hirarki (semakin } \\
\text { pusat semakin suci) }\end{array}$ & $\begin{array}{l}\text { Pemusatan Hirarki (semakin } \\
\text { pusat semakin suci) }\end{array}$ \\
\hline $\begin{array}{l}\text { Terdapat ruang patung di dalam } \\
\text { stupa yang tidak dapat diakses }\end{array}$ & Ruang utama berada tepat di pusat & $\begin{array}{l}\text { Ruang utama berada tepat di } \\
\text { pusat. }\end{array}$ \\
\hline 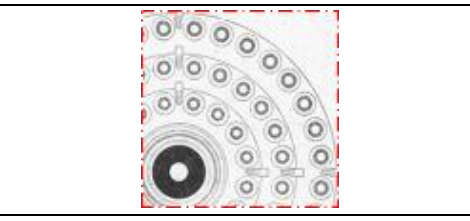 & 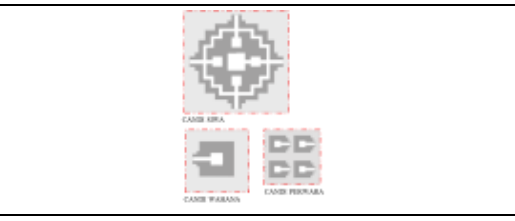 & tids \\
\hline $\begin{array}{l}\text { Perulangan bentuk denah } \\
\text { Bentuk denah stupa (lingkaran) } \\
\text { diulang pada stupa-stupa yang } \\
\text { lebih kecil }\end{array}$ & $\begin{array}{l}\text { Perulangan bentuk denah } \\
\text { Bentuk denah candi utama tidak } \\
\text { terulang pada candi lain, namun } \\
\text { denah candi wahana dan perwara } \\
\text { terulang }\end{array}$ & $\begin{array}{l}\text { Perulangan bentuk denah } \\
\text { Bentuk denah candi utama } \\
\text { terulang pada candi lain, namun } \\
\text { candi utama memiliki bentuk yang } \\
\text { lebih kompleks }\end{array}$ \\
\hline 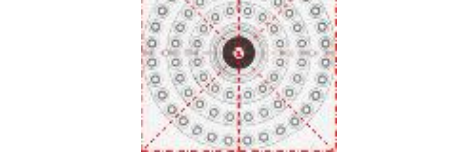 & 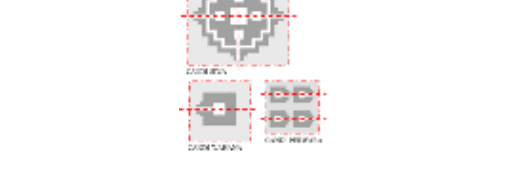 & 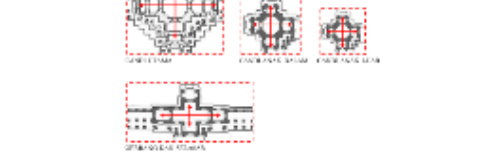 \\
\hline $\begin{array}{l}\text { Sisi Simetri } \\
\text { Berbentuk lingkaran sehingga } \\
\text { simetri pada semua bagian }\end{array}$ & $\begin{array}{l}\text { Sisi Simetri } \\
\text { Simetri pada keempat sisi } \\
\text { krusiform, namun akses pintu ke } \\
\text { ruang tengah hanya ada pada sisi } \\
\text { timur }\end{array}$ & $\begin{array}{l}\text { Sisi Simetri } \\
\text { Pada candi utama sisi simetri } \\
\text { seimbang pada keempat sisinya }\end{array}$ \\
\hline 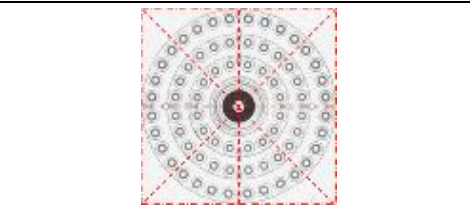 & 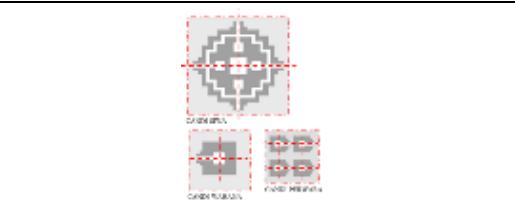 & 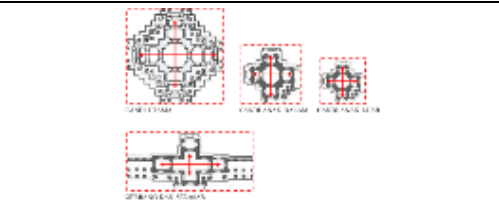 \\
\hline $\begin{array}{l}\text { Tipe Axis } \\
\text { Memusat }\end{array}$ & $\begin{array}{l}\text { Tipe Axis } \\
\text { Memusat sedikit linier, posisiruang } \\
\text { berada di pusat bangunan candi } \\
\text { namun dengan pintu masuk hanya } \\
\text { satu sisi (linier) }\end{array}$ & $\begin{array}{l}\text { Tipe Axis } \\
\text { Pada candi utama memiliki aksis } \\
\text { ke } 4 \text { arahnya. }\end{array}$ \\
\hline
\end{tabular}




\subsubsection{KOMPARASI SOSOK}

Komparasi unsur arsitektur candi pada konteks sosok akan dipaparkan melalui beberapa aspek yang dimiliki oleh unsur ini berdasarkan teori.

Tabel 3. Komparasi Unsur Arsitektur Sosok Borobudur dan Prambanan terhadap Angkor Wat Sumber gambar: Pusat Studi Angkor, Balai Penelitian Borobudur, dan Balai Pemugaran Cagar Budaya Yogyakarta; dengan modifikasi penulis

\begin{tabular}{|c|c|c|}
\hline \multicolumn{2}{|c|}{ Candi Rujukan } & Objek Candi \\
\hline Borobudur & Prambanan & Angkor Wat \\
\hline $\begin{array}{l}\text { Keserupaan dengan bentuk dasar } \\
\text { Terjadi ketimpangan pada } \\
\text { puncak Arupadhatu sehingga } \\
\text { membentuk kurva }\end{array}$ & $\begin{array}{l}\text { Keserupaan dengan bentuk } \\
\text { dasar } \\
\text { Lebih merepresentasikan bentuk } \\
\text { dasar segitiga pada sosok } \\
\text { keseluruhan dan sosok candi } \\
\text { tunggal. }\end{array}$ & $\begin{array}{l}\text { Keserupaan dengan bentuk } \\
\text { dasar } \\
\text { Lebih merepresentasikan bentuk } \\
\text { dasar segitiga pada sosok } \\
\text { keseluruhan dan sosok candi } \\
\text { tunggal. }\end{array}$ \\
\hline $\begin{array}{l}\text { Bentuk 3dimensi } \\
\text { Memiliki bentuk 3dimensi limas } \\
\text { dari bagian kamadhatu hingga } \\
\text { rupadhatu,dan kerucut pada } \\
\text { bagian arupadhatu. }\end{array}$ & $\begin{array}{l}\text { Bentuk 3dimensi } \\
\text { Memiliki bentuk } 3 \text { dimensi limas } \\
\text { tidak sama sisi pada sosok } \\
\text { keseluruhan dan limas sama sisi } \\
\text { pada candi tunggal }\end{array}$ & $\begin{array}{l}\text { Bentuk } 3 \text { dimensi } \\
\text { Memiliki bentuk } 3 \text { dimensi limas } \\
\text { tidak sama sisi pada sosok } \\
\text { keseluruhan dan limas sama sisi } \\
\text { pada candi-candi menara }\end{array}$ \\
\hline $\begin{array}{l}\text { Ruang void Candi Utama } \\
\text { Memiliki bentuk kerucut, tanpa } \\
\text { bukaan }\end{array}$ & $\begin{array}{l}\text { Ruang void Candi Utama } \\
\text { Memiliki bentuk limas yang } \\
\text { mengecil keatas. }\end{array}$ & $\begin{array}{l}\text { Ruang void Candi Utama } \\
\text { Memiliki bentuk limas yang } \\
\text { mengecil keatas. }\end{array}$ \\
\hline $\begin{array}{l}\text { Hirarki paling tinggi berada } \\
\text { puncak sosok segitiga } \\
\text { Stupa utama berada di posisi } \\
\text { paling tinggi. }\end{array}$ & $\begin{array}{l}\text { Hirarki paling tinggi berada } \\
\text { puncak sosok segitiga } \\
\text { Candi Siwa sebagai pusat hirarki } \\
\text { karena berada di pusat ketinggian. }\end{array}$ & $\begin{array}{l}\text { Hirarki paling tinggi berada } \\
\text { puncak sosok segitiga } \\
\text { Candi Utama sebagai pusat } \\
\text { hirarki karena berada di tempat } \\
\text { paling tinggi }\end{array}$ \\
\hline $\begin{array}{l}+ \\
=-8 \\
\end{array}$ & 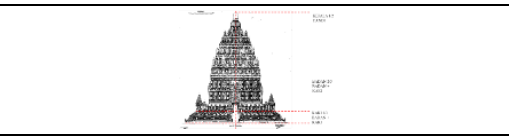 & 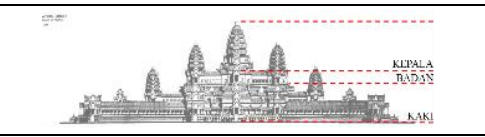 \\
\hline $\begin{array}{l}\text { Pembagian kepala-badan -kaki } \\
\text { Pembagian zona kamadhatu, } \\
\text { rupadhatu,dan arupadhatu pada } \\
\text { candi. }\end{array}$ & $\begin{array}{l}\text { Pembagian kepala-badan -kaki } \\
\text { Pada Prambanan alas candi-kaki, } \\
\text { dinding, pintu dan kolom -badan, } \\
\text { atap candi-kepala. }\end{array}$ & Pembagian kepala-badan -kaki \\
\hline ats & HUH & \\
\hline
\end{tabular}




\begin{tabular}{|c|c|c|}
\hline \multicolumn{2}{|c|}{ Candi Rujukan } & Objek Candi \\
\hline Borobudur & Prambanan & Angkor Wat \\
\hline $\begin{array}{l}\text { Perulangan sosok candi utama } \\
\text { pada candi anak. } \\
\text { Stupa-stupa kecil mengulang } \\
\text { bentuk stupa utama. }\end{array}$ & $\begin{array}{l}\text { Perulangan sosok candi utama } \\
\text { pada candi anak. } \\
\text { Candi-candi anak mengulang } \\
\text { sosok candi utama Siwa }\end{array}$ & $\begin{array}{l}\text { erulangan sosok candi utama } \\
\text { pada candi anak. } \\
\text { Candi-candi anak mengulang } \\
\text { sosok candi utama yang }\end{array}$ \\
\hline & 祖量 & \\
\hline $\begin{array}{l}\text { Sosok simetris bila dibelah pada } \\
\text { sumbu tengah }\end{array}$ & $\begin{array}{l}\text { Sosok simetris bila dibelah pada } \\
\text { sumbu tengah }\end{array}$ & $\begin{array}{l}\text { Sosok simetris bila dibelah pada } \\
\text { sumbu tengah }\end{array}$ \\
\hline $\begin{array}{l}\text { Mengambil sosok gunung. } \\
\text { Mewujudkan sosok gunung } \\
\text { dengan membuat candi } \\
\text { berundak-undak. }\end{array}$ & $\begin{array}{l}\text { Mengambil sosok gunung. } \\
\text { Mewujudkan sosok gunung dengan } \\
\text { membuat candi berundak-undak. }\end{array}$ & $\begin{array}{l}\text { Mengambil sosok gunung. } \\
\text { Mewujudkan sosok gunung dengan } \\
\text { membuat candi berundak-undak. }\end{array}$ \\
\hline $\begin{array}{l}\text { Mewujudkan Sosok Nirwana } \\
\text { pada bangunan. }\end{array}$ & $\begin{array}{l}\text { Mewujudkan Sosok Nirwana } \\
\text { pada bangunan. }\end{array}$ & $\begin{array}{l}\text { Mewujudkan Sosok Nirwana } \\
\text { pada bangunan. }\end{array}$ \\
\hline $\begin{array}{l}\text { Terbentuk pola permukaan fasad. } \\
\text { Terbentuk pola pembayangan } \\
\text { oleh lekukan candi secara } \\
\text { horizontal maupun vertikal. }\end{array}$ & $\begin{array}{l}\text { Bentuk pola permukaan fasad } \\
\text { Terbentuk pola pembayangan oleh } \\
\text { lekukan candi secara horizontal } \\
\text { maupun vertikal. }\end{array}$ & $\begin{array}{l}\text { Bentuk pola permukaan fasad } \\
\text { Terbentuk pola pembayangan oleh } \\
\text { lekukan candi secara horizontal } \\
\text { maupun vertikal. }\end{array}$ \\
\hline & 离 & A S S A \\
\hline $\begin{array}{l}\text { Proporsi Kepala Badan Kaki } \\
\text { Badan }+ \text { kaki candi=1/2 seluruh } \\
\text { bagian .Kaki }=1 / 3 \text { (badan+kaki) }\end{array}$ & $\begin{array}{l}\text { Proporsi Kepala Badan Kaki } \\
\text { Badan }+ \text { kaki candi }=1 / 2 \text { seluruh } \\
\text { bagian } \\
\text { Kaki }=1 / 3(\text { badan }+ \text { kaki })\end{array}$ & $\begin{array}{l}\text { Proporsi Kepala Badan Kaki } \\
\text { Badan }+ \text { kaki candi=1/2 seluruh } \\
\text { bagian }\end{array}$ \\
\hline
\end{tabular}

\subsubsection{KOMPARASI ORNAMEN}

Komparasi unsur arsitektur candi pada konteks ornamen akan dipaparkan melalui beberapa aspek yang dimiliki oleh unsur ini berdasarkan teori.

Tabel 4. Komparasi Unsur Arsitektur Sosok Borobudur dan Prambanan terhadap Angkor Wat Sumber gambar: Pusat Studi Angkor, Balai Penelitian Borobudur, dan Balai Pemugaran Cagar Budaya Yogyakarta; dengan modifikasi penulis 


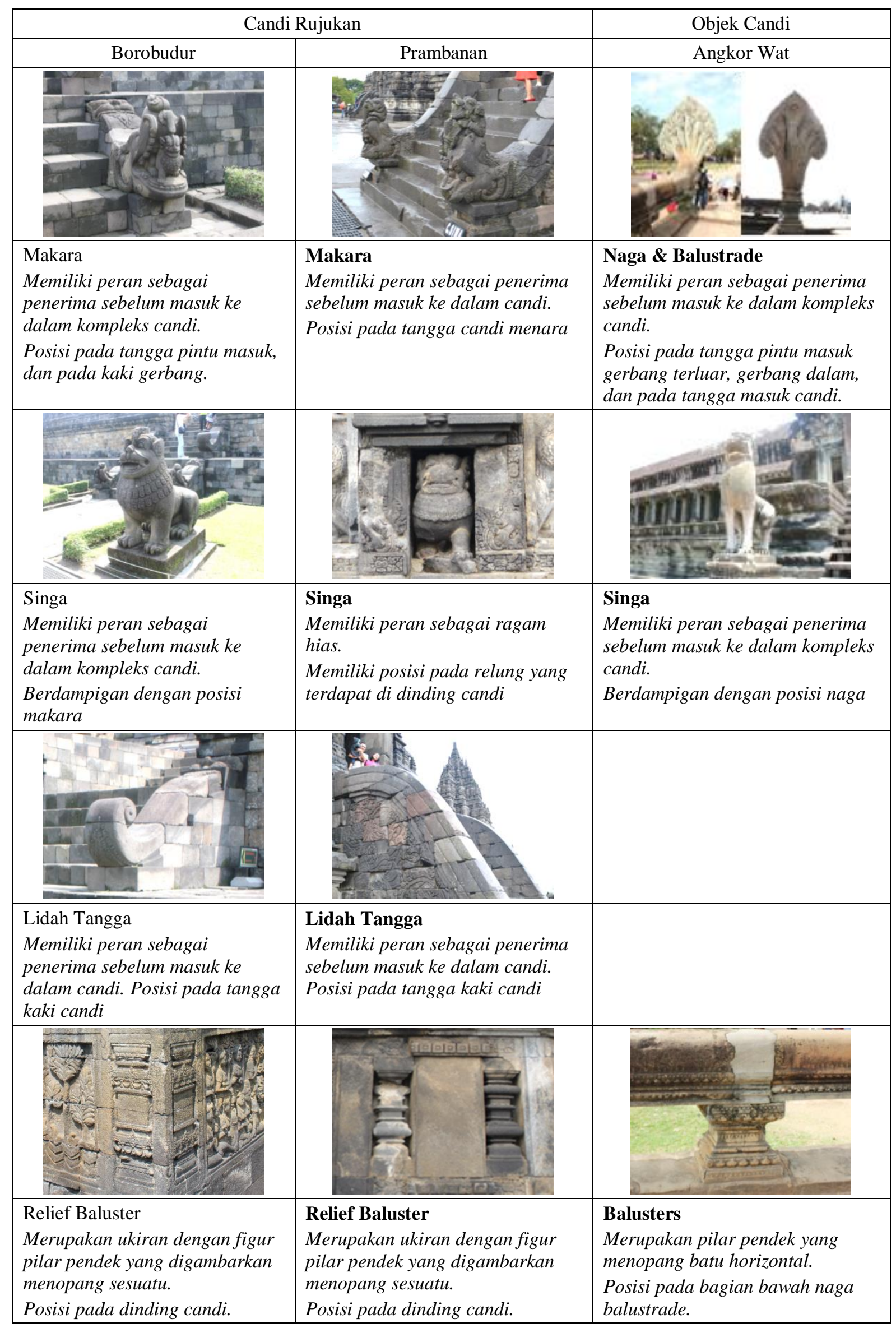




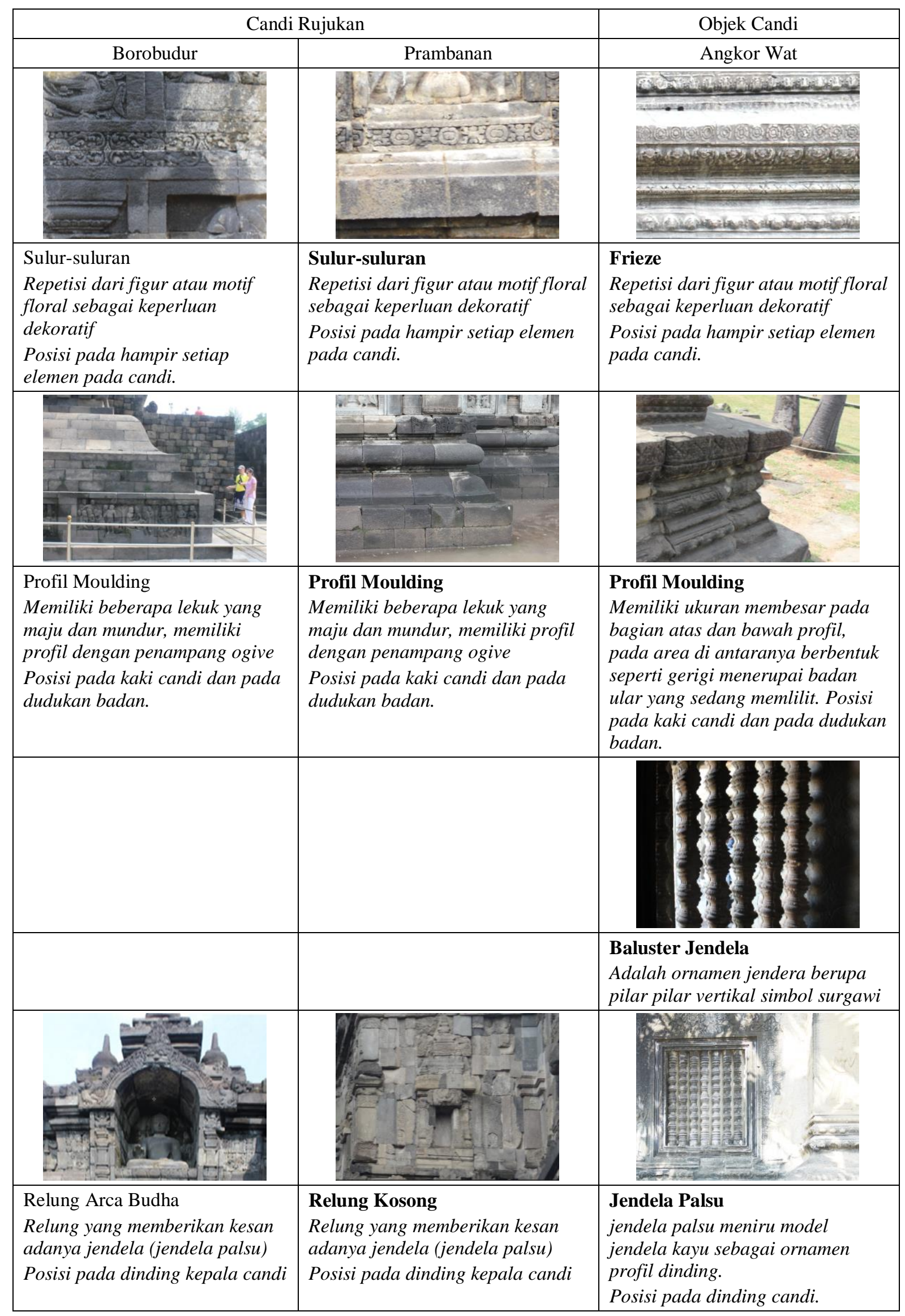




\begin{tabular}{|c|c|c|}
\hline \multicolumn{2}{|c|}{ Candi Rujukan } & Objek Candi \\
\hline Borobudur & Prambanan & Angkor Wat \\
\hline & $\begin{array}{l}\text { Pintu Palsu } \\
\text { Pintu palsu meniru model pintu } \\
\text { kayu sebagai ornamen profil } \\
\text { dinding. } \\
\text { Posisi pada dinding candi. }\end{array}$ & $\begin{array}{l}\text { Pintu Palsu } \\
\text { Pintu palsu meniru model pintu } \\
\text { kayu sebagai ornamen profil } \\
\text { dinding. } \\
\text { Posisi pada dinding candi. }\end{array}$ \\
\hline $\begin{array}{l}\text { Medalion } \\
\text { Dekorasi lingkaran yang } \\
\text { terbentuk dari sulur-suluran } \\
\text { Posisi pada dinding candi } \\
\text { (pagar galeri). }\end{array}$ & $\begin{array}{l}\text { Medalion } \\
\text { Dekorasi lingkaran yang terbentuk } \\
\text { dari sulur-suluran } \\
\text { Posisi pada dinding ruang dalam } \\
\text { candi dan sisi tangga }\end{array}$ & $\begin{array}{l}\text { Medalion } \\
\text { Dekorasi pada dinding candi dan } \\
\text { memiliki berbagai variasi figur di } \\
\text { tengah lingkaran. } \\
\text { Posisi pada dinding candi. }\end{array}$ \\
\hline & $\begin{array}{l}\text { Kertas Tempel } \\
\text { Motif bunga berpola persegi } \\
\text { Posisi pada dinding candi }\end{array}$ & \\
\hline & $\begin{array}{l}\text { Kalapataru dan Kinara Kinari } \\
\text { Merupakan dekorasi figur pohon } \\
\text { kehidupan dan sepasang burung }\end{array}$ & \\
\hline 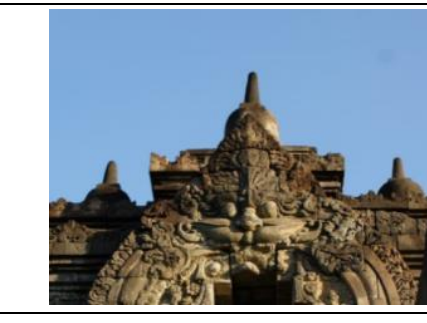 & 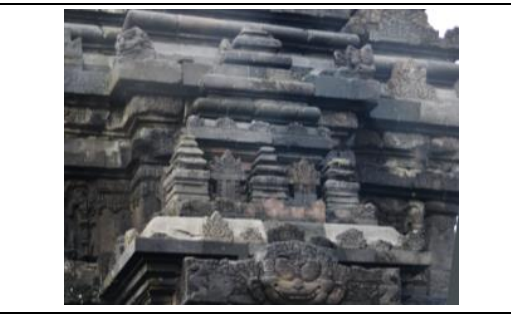 & 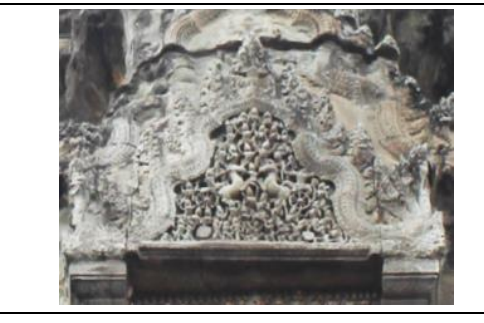 \\
\hline
\end{tabular}




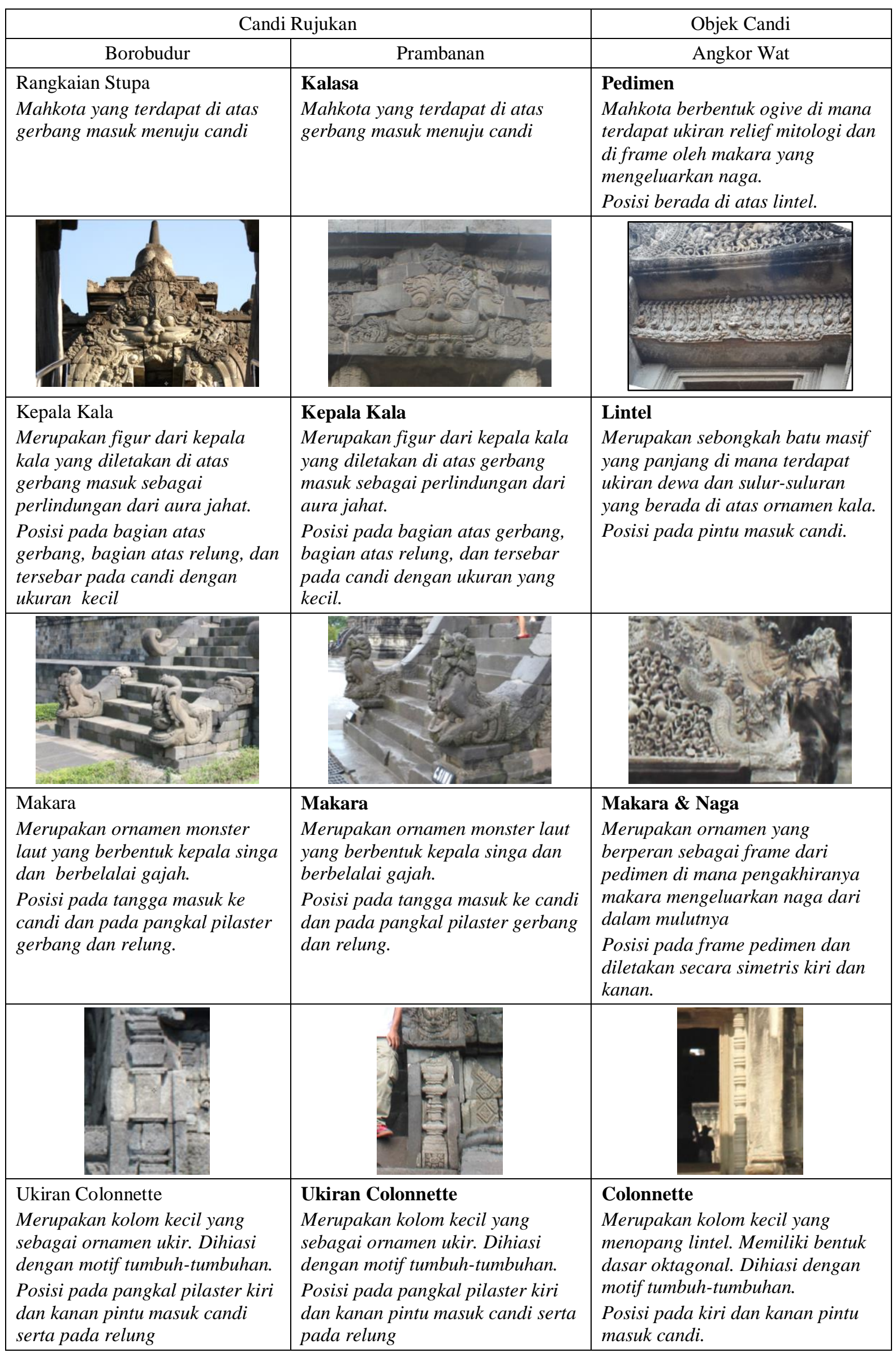




\begin{tabular}{|c|c|c|}
\hline \multicolumn{2}{|c|}{ Candi Rujukan } & Objek Candi \\
\hline Borobudur & Prambanan & Angkor Wat \\
\hline $\begin{array}{l}\text { Pilaster } \\
\text { Bagian dari dinding candi yang } \\
\text { menonjol keluar dan membentuk } \\
\text { kolom palsu dan biasanya } \\
\text { menopang kala. } \\
\text { Posisi pada kiri dan kanan jalur } \\
\text { pintu masuk. }\end{array}$ & $\begin{array}{l}\text { Pilaster } \\
\text { Bagian dari dinding candi yang } \\
\text { menonjol keluar dan membentuk } \\
\text { kolom palsu dan biasanya } \\
\text { menopang kala. } \\
\text { Posisi pada kiri dan kanan jalur } \\
\text { pintu masuk. }\end{array}$ & $\begin{array}{l}\text { Pilaster } \\
\text { Bagian dari dinding candi yang } \\
\text { menonjol keluar dan membentuk } \\
\text { kolom palsu dan biasanya } \\
\text { menopang lintel. } \\
\text { Posisi pada kiri dan kanan jalur } \\
\text { pintu masuk. }\end{array}$ \\
\hline W. & 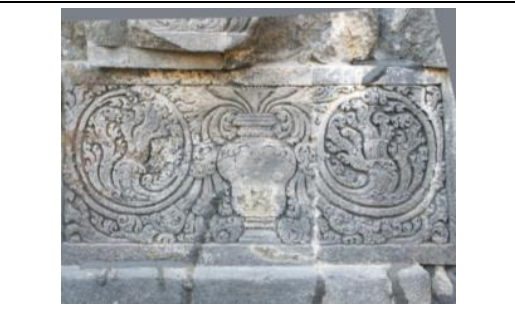 & \\
\hline $\begin{array}{l}\text { Purnakalasa } \\
\text { Merupakan ornamen sulur- } \\
\text { suluran kembar, simetris antara } \\
\text { sisi kiri dan kanan. Terdapat pot } \\
\text { pada tengahnya. }\end{array}$ & $\begin{array}{l}\text { Purnakalasa } \\
\text { Merupakan ornamen sulur-suluran } \\
\text { kembar, simetris antara sisi kiri } \\
\text { dan kanan. Terdapat pot pada } \\
\text { tengahnya. } \\
\text { Posisi pada dinding candi }\end{array}$ & $\begin{array}{l}\text { Purnakalasa } \\
\text { Merupakan ornamen sulur-suluran } \\
\text { kembar, simetris antara sisi kiri } \\
\text { dan kanan. Terdapat dewa pada } \\
\text { tengahnya. }\end{array}$ \\
\hline 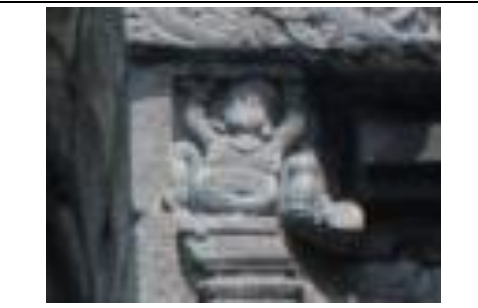 & & 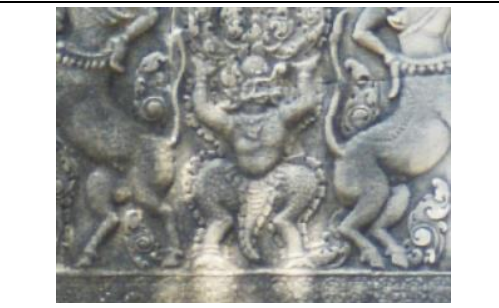 \\
\hline $\begin{array}{l}\text { Gana } \\
\text { Merupakan figur raksasa yang } \\
\text { menopang benda berat seperi } \\
\text { pilaster. Posisi pada pilaster } \\
\text { pintu candi. }\end{array}$ & $\begin{array}{l}\text { Gana } \\
\text { Merupakan figur raksasa yang } \\
\text { menopang benda berat seperi } \\
\text { pilaster. } \\
\text { Posisi pada pilaster pintu candi. }\end{array}$ & $\begin{array}{l}\text { Atlantes } \\
\text { Merupakan relief berupa garuda } \\
\text { atau singa yang menopang surga. } \\
\text { Posisi pada relef dinding. }\end{array}$ \\
\hline & 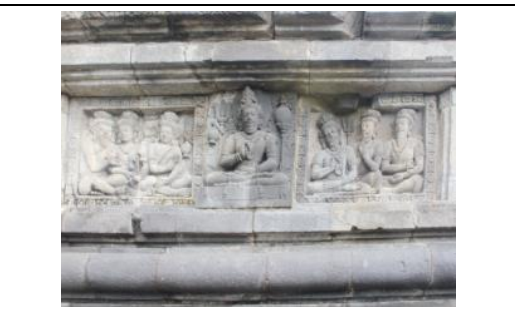 & \\
\hline & $\begin{array}{l}\text { Pendeta } \\
\text { Merupakan sosok pria berjangut } \\
\text { dengan tangan memegang tasbih } \\
\text { dan kaki menyilang. } \\
\text { Posisi pada dinding candi }\end{array}$ & $\begin{array}{l}\text { Pendeta } \\
\text { Merupakan sosok pria berjangut } \\
\text { dengan tangan terkatup dan kaki } \\
\text { menyilang. } \\
\text { Posisi pada pangkal kolom galeri. }\end{array}$ \\
\hline
\end{tabular}




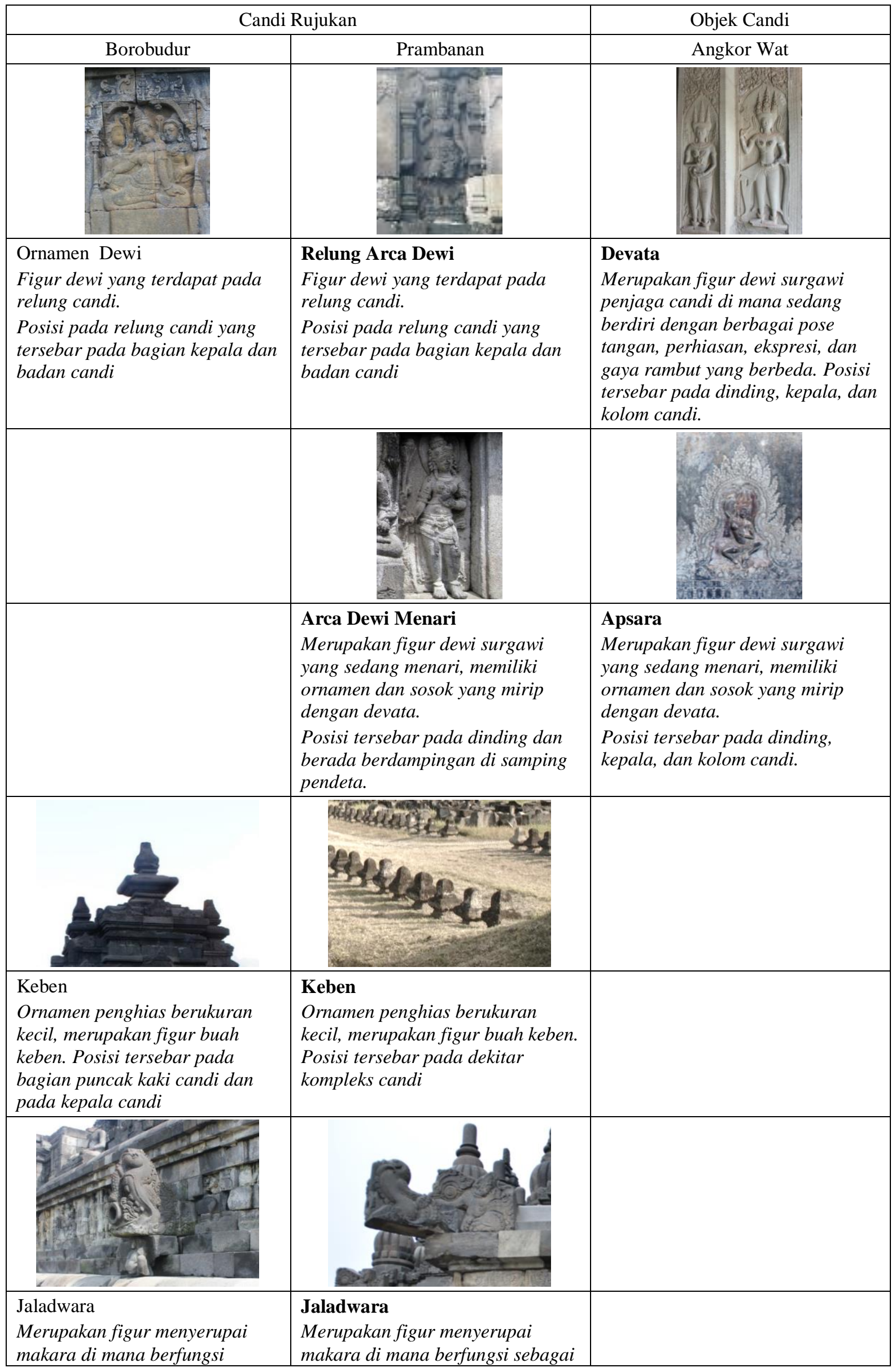




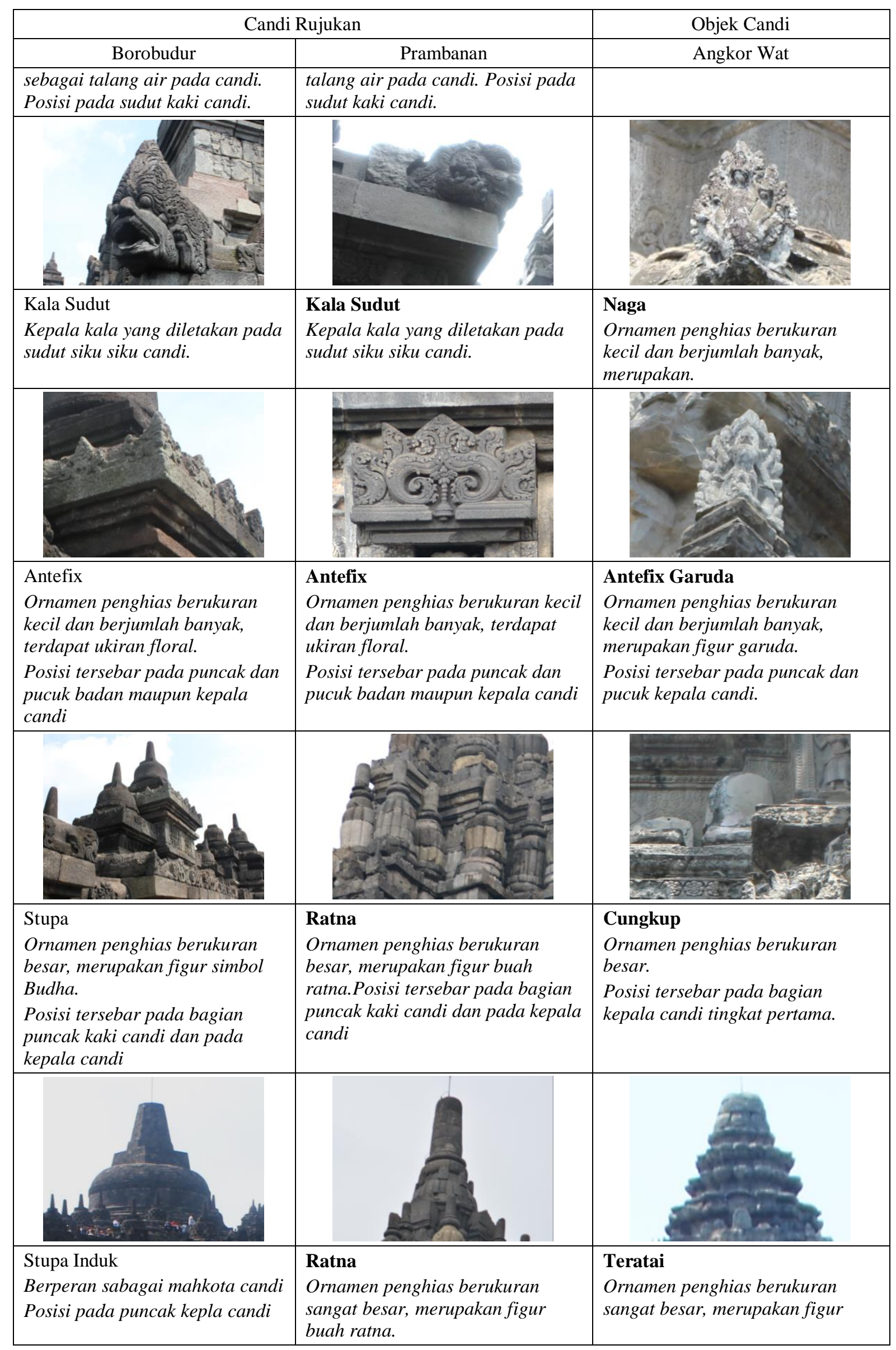




\begin{tabular}{|c|c|c|}
\hline \multicolumn{2}{|c|}{ Candi Rujukan } & Objek Candi \\
\hline Borobudur & Prambanan & Angkor Wat \\
\hline & Posisi pada puncak kepala candi & $\begin{array}{l}\text { teratai yang sedang mekar. Posisi } \\
\text { pada puncak }\end{array}$ \\
\hline
\end{tabular}

\subsection{HASIL KOMPARASI UNSUR ARSITEKTUR}

Setelah melakukan analisis komparasi unsur arsitektur Borobudur dan Prambanan terhdadap Angkor Wat dari unsur tata massa, denah, sosok, dan ornamen; maka komparasi tersebut dapat dirangkum dan disederhanakan seperti berikut:

\subsubsection{KOMPARASI TATA MASSA}

Berikut akan dipaparkan tabel checklist komparasi dan tabel rekapitulasi perhitungan dari analisis komparasi unsur arsitektur tata massa.

Tabel 5. Rangkuman Komparasi Unsur Arsitektur Tata Massa Borobudur dan Prambanan terhadap Angkor Wat

\begin{tabular}{|c|c|c|c|c|c|c|c|c|}
\hline \multirow{3}{*}{ Kode } & \multirow{3}{*}{ Aspek } & \multirow{3}{*}{ Kriteria } & \multicolumn{3}{|c|}{$\mathrm{B} \rightarrow \mathrm{AW}$} & \multicolumn{3}{|c|}{$\mathrm{P} \rightarrow \mathrm{AW}$} \\
\hline & & & \multirow{2}{*}{$\begin{array}{l}\mathbf{T} \\
\mathbf{A}\end{array}$} & \multicolumn{2}{|c|}{$\mathbf{A}$} & \multirow{2}{*}{$\begin{array}{l}\mathbf{T} \\
\mathbf{A}\end{array}$} & \multicolumn{2}{|c|}{$\mathbf{A}$} \\
\hline & & & & $\begin{array}{l}\mathbf{T} \\
\mathbf{S}\end{array}$ & $\mathbf{S}$ & & $\begin{array}{l}T \\
\mathbf{S}\end{array}$ & $\mathbf{S}$ \\
\hline 4.1.1 & Mandala & Penerapan Mandala & & $\mathrm{O}$ & & & & $\mathrm{O}$ \\
\hline \multirow{2}{*}{ 4.1.2 } & \multirow{2}{*}{ Geometrik } & Bentuk Dasar Tapak & & $\mathrm{O}$ & & & $\mathrm{O}$ & \\
\hline & & Penggabungan Geometri tapak & & $\mathrm{O}$ & & & $\mathrm{O}$ & \\
\hline \multirow[t]{2}{*}{ 4.1.3 } & \multirow{2}{*}{$\begin{array}{l}\text { Solid - void - } \\
\quad \text { Cluster }\end{array}$} & $\begin{array}{l}\text { Koridor yang dibentuk tatanan } \\
\text { solid }\end{array}$ & & $\mathrm{O}$ & & & $\mathrm{O}$ & \\
\hline & & Area void (masa renggang) & & & $\mathrm{O}$ & & & $\mathrm{O}$ \\
\hline \multirow{3}{*}{ 4.1.4 } & \multirow{3}{*}{$\begin{array}{l}\text { Hirarki dan } \\
\text { Pembagian } \\
\text { Tiga }\end{array}$} & $\begin{array}{l}\text { Jumlah Hirarki pada Tapak } \\
\text { (kosmologi) }\end{array}$ & & $\mathrm{O}$ & & & $\mathrm{O}$ & \\
\hline & & $\begin{array}{l}\text { Jumlah Hirarki pada Tapak } \\
\text { (undakan) }\end{array}$ & & & $\mathrm{O}$ & & & $\mathrm{O}$ \\
\hline & & Pemusatan Hirarki (semakin suci) & & $\mathrm{O}$ & & & & $\mathrm{O}$ \\
\hline 4.1.5 & $\begin{array}{l}\text { Irama- } \\
\text { Perulangan- } \\
\text { Datum }\end{array}$ & Perulangan bentuk dasar geometrik & & & $\mathrm{O}$ & & $\mathrm{O}$ & \\
\hline 4.1.6 & $\begin{array}{l}\text { Simetri- } \\
\text { Seimbang }\end{array}$ & Sisi Simetri & & $\mathrm{O}$ & & & & $\mathrm{O}$ \\
\hline \multirow{2}{*}{ 4.1.7 } & \multirow{2}{*}{$\begin{array}{c}\text { Sumbu / Axis- } \\
\text { Linier- } \\
\text { Memusat }\end{array}$} & Axis Memusat & & & $\mathrm{O}$ & & & $\mathrm{O}$ \\
\hline & & Axis Linier & & $\mathrm{O}$ & & & & $\mathrm{O}$ \\
\hline
\end{tabular}

Legenda:

B:Borobudur; P:Prambanan; AW:Angkor Wat; O: Tanda Cek;

TA:Tidak Ada; A:Ada; TS:Tidak Serupa; S: Serupa

\subsubsection{KOMPARASI DENAH}

Berikut akan dipaparkan tabel checklist komparasi dan tabel perhitungan dari analisis komparasi unsur arsitektur denah. 
Tabel 6. Rangkuman Komparasi Unsur Arsitektur Denah Borobudur dan Prambanan terhadap Angkor Wat

\begin{tabular}{|c|c|c|c|c|c|c|c|c|}
\hline \multirow{3}{*}{ Kode } & \multirow{3}{*}{ Aspek } & \multirow{3}{*}{ Kriteria } & \multicolumn{3}{|c|}{$B \rightarrow A W$} & \multicolumn{3}{|c|}{$P \rightarrow A W$} \\
\hline & & & \multirow{2}{*}{$\begin{array}{l}\mathbf{T} \\
\mathbf{A}\end{array}$} & \multicolumn{2}{|c|}{$\mathbf{A}$} & \multirow{2}{*}{$\begin{array}{l}\mathbf{T} \\
\mathbf{A}\end{array}$} & \multicolumn{2}{|c|}{$\mathbf{A}$} \\
\hline & & & & $\begin{array}{l}\mathbf{T} \\
\mathbf{S}\end{array}$ & $\mathbf{S}$ & & $\begin{array}{l}\mathbf{T} \\
\mathbf{S}\end{array}$ & $\mathbf{S}$ \\
\hline 4.2.1 & Mandala & Penerapan Mandala & & $\mathrm{O}$ & & & & $\mathrm{O}$ \\
\hline \multirow{2}{*}{ 4.2.2 } & \multirow{2}{*}{$\begin{array}{l}\text { Geometrik } \\
\text { Kartesian - } \\
\text { Cruciform }\end{array}$} & Bentuk Dasar Denah & & $\mathrm{O}$ & & & & $\mathrm{O}$ \\
\hline & & Penggabungan Geometri Denah & & $\mathrm{O}$ & & & & $\mathrm{O}$ \\
\hline \multirow{2}{*}{ 4.2.3 } & \multirow{2}{*}{$\begin{array}{l}\text { Solid - Void - } \\
\text { Cluster }\end{array}$} & Area Aktivitas & & $\mathrm{O}$ & & & & $\mathrm{O}$ \\
\hline & & Ruang void Candi Utama & & $\mathrm{O}$ & & & & $\mathrm{O}$ \\
\hline 4.2 .4 & Hirarki & Pemusatan Hirarki (semakin suci) & & & $\mathrm{O}$ & & & $\mathrm{O}$ \\
\hline 4.2 .5 & $\begin{array}{l}\text { Irama- } \\
\text { Perulangan- } \\
\text { Datum }\end{array}$ & Perulangan bentuk denah & & & $\mathrm{O}$ & & $\mathrm{O}$ & \\
\hline 4.2.6 & $\begin{array}{l}\text { Simetris- } \\
\text { Seimbang }\end{array}$ & Sisi Simetri & & $\mathrm{O}$ & & & & $\mathrm{O}$ \\
\hline 4.2 .7 & $\begin{array}{c}\text { Sumbu/ Axis - } \\
\text { Linier - } \\
\text { Memusat }\end{array}$ & Tipe Axis & & & $\mathrm{O}$ & & $\mathrm{O}$ & \\
\hline
\end{tabular}

Legenda:

B:Borobudur; P:Prambanan; AW:Angkor Wat; O: Tanda Cek;

TA:Tidak Ada; A:Ada; TS:Tidak Serupa; S: Serupa

\subsubsection{KOMPARASI SOSOK}

Berikut akan dipaparkan tabel checklist komparasi dan tabel rekapitulasi perhitungan dari analisis komparasi unsur arsitektur sosok.

Tabel 7. Rangkuman Komparasi Unsur Arsitektur Sosok Borobudur dan Prambanan terhadap Angkor Wat

\begin{tabular}{|c|c|c|c|c|c|c|c|c|}
\hline \multirow{3}{*}{ Kode } & \multirow{3}{*}{ Aspek } & \multirow{3}{*}{ Kriteria } & \multicolumn{3}{|c|}{$B \rightarrow A W$} & \multicolumn{3}{|c|}{$P \rightarrow A W$} \\
\hline & & & \multirow{2}{*}{$\mathbf{T}$} & \multicolumn{2}{|c|}{$\mathbf{A}$} & \multirow{2}{*}{$\begin{array}{l}\mathbf{T} \\
\mathbf{A}\end{array}$} & \multicolumn{2}{|c|}{$\mathbf{A}$} \\
\hline & & & & $\begin{array}{l}\mathbf{T} \\
\mathbf{S}\end{array}$ & $\mathbf{S}$ & & $\begin{array}{l}\mathbf{T} \\
\mathbf{S}\end{array}$ & $\mathbf{S}$ \\
\hline 4.3.1 & $\begin{array}{l}\text { Komposisi } \\
\text { Geometrik } \\
\text { Kartesian }\end{array}$ & Keserupaan dengan bentuk dasar & & & $\mathrm{O}$ & & & $\mathrm{O}$ \\
\hline \multirow{2}{*}{ 4.3.2 } & \multirow{2}{*}{ Volumetrik } & Bentuk tiga dimensi & & $\mathrm{O}$ & & & & $\mathrm{O}$ \\
\hline & & Ruang void Candi Utama & & $\mathrm{O}$ & & & & $\mathrm{O}$ \\
\hline 4.3.3 & $\begin{array}{l}\text { Hirarki- } \\
\text { Segitiga }\end{array}$ & $\begin{array}{l}\text { Hirarki paling tinggi berada } \\
\text { puncak }\end{array}$ & & & $\mathrm{O}$ & & & $\mathrm{O}$ \\
\hline 4.3.4 & $\begin{array}{l}\text { Pembagian } \\
\text { Tiga }\end{array}$ & Pembagian kepala-badan -kaki & & & $\mathrm{O}$ & & & $\mathrm{O}$ \\
\hline 4.3.5 & $\begin{array}{l}\text { Perulangan- } \\
\text { Datum }\end{array}$ & $\begin{array}{l}\text { Perulangan sosok candi utama } \\
\text { pada candi anak. }\end{array}$ & & & $\mathrm{O}$ & & & $\mathrm{O}$ \\
\hline
\end{tabular}




\begin{tabular}{|c|c|l|l|l|l|l|l|l|}
\hline 4.3.6 & $\begin{array}{c}\text { Simetri - } \\
\text { Pusat } \\
\text { Perhatian - } \\
\text { Seimbang }\end{array}$ & $\begin{array}{l}\text { Sosok simetris bila dibelah pada } \\
\text { sumbu tengah }\end{array}$ & & O & & O \\
\hline \multirow{2}{*}{ 4.3.7 } & Mimesis & Mengambil sosok gunung. & & & $\mathrm{O}$ & & & $\mathrm{O}$ \\
\hline & Mewujudkan Sosok Nirwana & & & $\mathrm{O}$ & & & $\mathrm{O}$ \\
\hline $\mathbf{4 . 3 . 8}$ & Tekstur & Bentuk pola permukaan fasad & & & $\mathrm{O}$ & & $\mathrm{O}$ \\
\hline 4.3.9 & $\begin{array}{c}\text { Proporsi, } \\
\text { Skala }\end{array}$ & Proporsi Kepala Badan Kaki & & $\mathrm{O}$ & & & $\mathrm{O}$ \\
\hline
\end{tabular}

Legenda:

B:Borobudur; P:Prambanan; AW:Angkor Wat; O: Tanda Cek; TA:Tidak Ada; A:Ada; TS:Tidak Serupa; S: Serupa

\subsubsection{KOMPARASI ORNAMEN}

Berikut akan dipaparkan tabel checklist komparasi dan tabel rekapitulasi perhitungan dari analisis komparasi unsur arsitektur ornamen.

Tabel 8. Rangkuman Komparasi Unsur Arsitektur Sosok Borobudur dan Prambanan terhadap Angkor Wat

\begin{tabular}{|c|c|c|c|c|c|c|c|}
\hline Kode & Ragam Hias & \multicolumn{2}{|c|}{ Status } & B & $\mathbf{P}$ & $\mathbf{A W}$ & Keterangan \\
\hline \multirow{3}{*}{ 4.4.1 } & \multirow{3}{*}{$\begin{array}{l}\text { Penerima (Makara \& } \\
\text { Naga-baluster) }\end{array}$} & \multirow{2}{*}{ A } & $\mathrm{S}$ & $\mathrm{O}$ & $\mathrm{O}$ & & \multirow{3}{*}{$\begin{array}{l}\text { Fungsi dan posisi } \\
\text { serupa, jenis ornamen } \\
\text { berbeda. }\end{array}$} \\
\hline & & & $\mathrm{TS}$ & & & $\mathrm{O}$ & \\
\hline & & \multicolumn{2}{|c|}{ TA } & & & & \\
\hline \multirow{3}{*}{ 4.4.2 } & \multirow{3}{*}{ Singa } & \multirow{2}{*}{ A } & $\mathrm{S}$ & $\mathrm{O}$ & & $\mathrm{O}$ & \multirow{3}{*}{$\begin{array}{l}\text { Serupa dengan salah } \\
\text { satu candi rujukan }\end{array}$} \\
\hline & & & $\mathrm{TS}$ & & $\mathrm{O}$ & & \\
\hline & & \multicolumn{2}{|c|}{ TA } & & & & \\
\hline \multirow{3}{*}{4.4 .3} & \multirow{3}{*}{ Lidah Tangga } & \multirow{2}{*}{ A } & $\mathrm{S}$ & & & & \multirow{3}{*}{$\begin{array}{l}\text { Tidak ditemukan pada } \\
\text { Angkor Wat }\end{array}$} \\
\hline & & & TS & O & 0 & & \\
\hline & & \multicolumn{2}{|c|}{ TA } & & & $\mathrm{O}$ & \\
\hline \multirow{3}{*}{ 4.4.4 } & \multirow{3}{*}{ Baluster } & \multirow{2}{*}{ A } & $\mathrm{S}$ & $\mathrm{O}$ & $\mathrm{O}$ & & \multirow{3}{*}{$\begin{array}{l}\text { Terhadap Angkor Wat } \\
\text { tidak Serupa }\end{array}$} \\
\hline & & & $\mathrm{TS}$ & & & $\mathrm{O}$ & \\
\hline & & \multicolumn{2}{|c|}{ TA } & & & & \\
\hline \multirow{3}{*}{ 4.4.5 } & \multirow{3}{*}{$\begin{array}{l}\text { Frieze dan Sulur- } \\
\text { Suluran }\end{array}$} & \multirow{2}{*}{ A } & $\mathrm{S}$ & $\mathrm{O}$ & $\mathrm{O}$ & & \multirow{3}{*}{$\begin{array}{l}\text { Terhadap Angkor Wat } \\
\text { tidak Serupa }\end{array}$} \\
\hline & & & $\mathrm{TS}$ & & & $\mathrm{O}$ & \\
\hline & & \multicolumn{2}{|c|}{ TA } & & & & \\
\hline \multirow{3}{*}{3.4 .6} & \multirow{3}{*}{ Profil Moulding } & \multirow{2}{*}{ A } & $\mathrm{S}$ & $\mathrm{O}$ & $\mathrm{O}$ & & \multirow{3}{*}{$\begin{array}{l}\text { Terhadap Angkor Wat } \\
\text { tidak Serupa }\end{array}$} \\
\hline & & & $\mathrm{TS}$ & & & $\mathrm{O}$ & \\
\hline & & \multicolumn{2}{|c|}{ TA } & & & & \\
\hline & & & $\mathrm{S}$ & & & & \\
\hline 4.4.7 & Baluster Jendela & A & $\mathrm{TS}$ & & & O & $\begin{array}{l}\text { Hanya ditemukan pada } \\
\text { Angkor Wat }\end{array}$ \\
\hline & & & & $\mathrm{O}$ & $\mathrm{O}$ & & \\
\hline & & & $S$ & & $\mathrm{O}$ & $\mathrm{O}$ & \\
\hline 4.4.8 & $\begin{array}{l}\text { Relung dan Jendela } \\
\text { Palsu }\end{array}$ & A & $\mathrm{TS}$ & $\mathrm{O}$ & & & $\begin{array}{l}\text { Serupa dengan salah } \\
\text { satu candi rujukan }\end{array}$ \\
\hline & & & & & & & \\
\hline & & & $\mathrm{S}$ & & & & \\
\hline 4.4.9 & Pintu Palsu & A & $\mathrm{TS}$ & & $\mathrm{O}$ & $\mathrm{O}$ & $\begin{array}{l}\text { Terhadap Angkor Wat } \\
\text { tidak Serupa }\end{array}$ \\
\hline & & & & $\mathrm{O}$ & & & \\
\hline 4.4.10 & Medalion & A & $\mathrm{S}$ & $\mathrm{O}$ & $\mathrm{O}$ & $\mathrm{O}$ & \\
\hline
\end{tabular}




\begin{tabular}{|c|c|c|c|c|c|c|c|}
\hline Kode & Ragam Hias & \multicolumn{2}{|c|}{ Status } & B & $\mathbf{P}$ & AW & Keterangan \\
\hline & & & TS & & & & Serupa dengan kedua \\
\hline & & \multicolumn{2}{|c|}{ TA } & & & & candi rujukan \\
\hline \multirow{3}{*}{ 4.4.11 } & \multirow{3}{*}{ Kertas Tempel } & \multirow{2}{*}{ A } & $S$ & & $\Omega$ & & \multirow{3}{*}{$\begin{array}{l}\text { Tidak ditemukan pada } \\
\text { Angkor Wat }\end{array}$} \\
\hline & & & TS & & U & & \\
\hline & & \multicolumn{2}{|c|}{ TA } & $\mathrm{O}$ & & $\mathrm{O}$ & \\
\hline \multirow{3}{*}{ 4.4.12 } & \multirow{3}{*}{$\begin{array}{c}\text { Kalpataru dan Kinara } \\
\text { Kinari }\end{array}$} & \multirow{2}{*}{ A } & $S$ & & 0 & & \multirow{3}{*}{$\begin{array}{l}\text { Tidak ditemukan pada } \\
\text { Angkor Wat }\end{array}$} \\
\hline & & & $\mathrm{TS}$ & & $\mathrm{U}$ & & \\
\hline & & \multicolumn{2}{|c|}{ TA } & $\mathrm{O}$ & & $\mathrm{O}$ & \\
\hline \multirow{3}{*}{ 4.4.13 } & \multirow{3}{*}{ Mahkota Gerbang } & \multirow{2}{*}{ A } & $\mathrm{S}$ & $\mathrm{O}$ & $\mathrm{O}$ & & \multirow{3}{*}{$\begin{array}{l}\text { Fungsi dan posisi } \\
\text { serupa, jenis ornamen } \\
\text { berbeda. }\end{array}$} \\
\hline & & & TS & & & $\mathrm{O}$ & \\
\hline & & \multicolumn{2}{|c|}{ TA } & & & & \\
\hline \multirow{3}{*}{ 4.4.14 } & \multirow{3}{*}{ Pedimen Atas } & \multirow{2}{*}{ A } & $S$ & & & O & \\
\hline & & & $\mathrm{TS}$ & & & 0 & Hanya ditemukan pada \\
\hline & & & & $\mathrm{O}$ & $\mathrm{O}$ & & \\
\hline & & $\Delta$ & S & & & O & \\
\hline 4.4.15 & Pedimen Samping & A & TS & & & 0 & Hanya ditemukan pada \\
\hline & & & & $\mathrm{O}$ & $\mathrm{O}$ & & \\
\hline & & & $\mathrm{S}$ & $\mathrm{O}$ & $\mathrm{O}$ & $\mathrm{O}$ & \\
\hline 4.4.16 & Kepala Kala dan Lintel & A & TS & & & & Serupa dengan kedua \\
\hline & & & & & & & \\
\hline & & $\Delta$ & $S$ & $\mathrm{O}$ & $\mathrm{O}$ & & Fungsi dan posisi \\
\hline 4.4.17 & $\begin{array}{l}\text { Makara-Singa dan } \\
\text { Makara-Naga }\end{array}$ & $\mathrm{A}$ & TS & & & $\mathrm{O}$ & serupa, jenis ornamen \\
\hline & & & & & & & berbeda \\
\hline & & $\Lambda$ & $S$ & $\mathrm{O}$ & $\mathrm{O}$ & & \\
\hline 4.4.18 & Colonnette & $\mathrm{A}$ & $\mathrm{TS}$ & & & $\mathrm{O}$ & $\begin{array}{l}\text { Terhadap Angkor Wat } \\
\text { tidak Serupa }\end{array}$ \\
\hline & & & & & & & \\
\hline & & $A$ & $S$ & $\mathrm{O}$ & $\mathrm{O}$ & $\mathrm{O}$ & \\
\hline 4.4.19 & Pilaster & $\mathrm{A}$ & $\mathrm{TS}$ & & & & $\begin{array}{l}\text { Serupa dengan kedua } \\
\text { candi ruiukan }\end{array}$ \\
\hline & & & & & & & \\
\hline & & 4 & S & & & O & \\
\hline 4.4.20 & Ambang Pintu & A & TS & & & 0 & Hanya ditemukan pada \\
\hline & & & & $\mathrm{O}$ & $\mathrm{O}$ & & \\
\hline & & $\Delta$ & $S$ & $\mathrm{O}$ & $\mathrm{O}$ & & \\
\hline 4.4.21 & Purnakalasa & A & TS & & & $\mathrm{O}$ & Terhadap Angkor Wat \\
\hline & & & & & & & \\
\hline & & $\Lambda$ & $S$ & $\mathrm{O}$ & $\mathrm{O}$ & & \\
\hline 4.4.22 & Gana dan Atlantes & A & TS & & & $\mathrm{O}$ & Terhadap Angkor Wat \\
\hline & & & & & & & \\
\hline & & & & & & & \\
\hline & & A & $S$ & & & $\mathrm{O}$ & \\
\hline 4.4.23 & Dewa Membunuh Iblis & & $\mathrm{TS}$ & & & & $\begin{array}{l}\text { Hanya ditemukan pada } \\
\text { Anokor Wat }\end{array}$ \\
\hline & & & & $\mathrm{O}$ & $\mathrm{O}$ & & \\
\hline & & & $S$ & & & & \\
\hline 4.4.24 & Penderta & A & TS & & $\mathrm{O}$ & $\mathrm{O}$ & Terhadap Angkor Wat \\
\hline & & & & $\mathrm{O}$ & & & \\
\hline & & $\Delta$ & $S$ & & & & \\
\hline 4.4.25 & Devata & A & TS & $\mathrm{O}$ & $\mathrm{O}$ & $\mathrm{O}$ & $\begin{array}{l}\text { Terhadap Angkor Wat } \\
\text { tidak Serupa }\end{array}$ \\
\hline & & & & & & & \\
\hline 4.4.26 & Dewi Menari & A & $S$ & & & & \\
\hline
\end{tabular}




\begin{tabular}{|c|c|c|c|c|c|c|c|}
\hline Kode & Ragam Hias & \multicolumn{2}{|c|}{ Status } & B & $\mathbf{P}$ & $\mathbf{A W}$ & Keterangan \\
\hline & & & $\mathrm{TS}$ & & $\mathrm{O}$ & $\mathrm{O}$ & Terhadap Angkor Wat \\
\hline & & \multicolumn{2}{|c|}{ TA } & $\mathrm{O}$ & & & tidak Serupa \\
\hline \multirow{3}{*}{ 4.4.27 } & \multirow{3}{*}{ Keben } & \multirow{2}{*}{ A } & S & & & & \multirow{3}{*}{$\begin{array}{l}\text { Tidak ditemukan pada } \\
\text { Angkor Wat }\end{array}$} \\
\hline & & & TS & U & 0 & & \\
\hline & & \multicolumn{2}{|c|}{ TA } & & & $\mathrm{O}$ & \\
\hline \multirow{3}{*}{ 4.4.28 } & \multirow{3}{*}{ Jaladwara } & \multirow{2}{*}{ A } & $\mathrm{S}$ & ? & 0 & & \multirow{3}{*}{$\begin{array}{l}\text { Tidak ditemukan pada } \\
\text { Angkor Wat }\end{array}$} \\
\hline & & & TS & U & U & & \\
\hline & & \multicolumn{2}{|c|}{ TA } & & & $\mathrm{O}$ & \\
\hline \multirow{3}{*}{ 4.4.29 } & \multirow{3}{*}{ Kala Sudut dan Naga } & \multirow{2}{*}{ A } & $\mathrm{S}$ & $\mathrm{O}$ & $\mathrm{O}$ & & \multirow{3}{*}{$\begin{array}{l}\text { Fungsi dan posisi } \\
\text { serupa, jenis ornamen } \\
\text { berbeda. }\end{array}$} \\
\hline & & & TS & & & $\mathrm{O}$ & \\
\hline & & \multicolumn{2}{|c|}{ TA } & & & & \\
\hline \multirow{3}{*}{ 4.4.30 } & \multirow{3}{*}{ Antefix } & \multirow{2}{*}{ A } & $\mathrm{S}$ & $\mathrm{O}$ & $\mathrm{O}$ & & \multirow{3}{*}{$\begin{array}{l}\text { Fungsi dan posisi } \\
\text { serupa, jenis ornamen } \\
\text { berbeda. }\end{array}$} \\
\hline & & & TS & & & $\mathrm{O}$ & \\
\hline & & \multicolumn{2}{|c|}{ TA } & & & & \\
\hline \multirow{3}{*}{ 4.4.31 } & \multirow{3}{*}{$\begin{array}{l}\text { Riasan Atap Dominan } \\
\text { (Stupa, Ratna, dan } \\
\text { Cungkup) }\end{array}$} & \multirow{2}{*}{ A } & $\mathrm{S}$ & & & & \multirow{3}{*}{$\begin{array}{l}\text { Fungsi dan posisi } \\
\text { serupa, jenis ornamen } \\
\text { berbeda. }\end{array}$} \\
\hline & & & $\mathrm{TS}$ & $\mathrm{O}$ & $\mathrm{O}$ & $\mathrm{O}$ & \\
\hline & & \multicolumn{2}{|c|}{ TA } & & & & \\
\hline \multirow{3}{*}{ 4.4.32 } & \multirow{3}{*}{ Riasan Atap Puncak } & \multirow{2}{*}{ A } & $\mathrm{S}$ & & & & \multirow{3}{*}{$\begin{array}{l}\text { Fungsi dan posisi } \\
\text { serupa, jenis ornamen } \\
\text { berbeda. }\end{array}$} \\
\hline & & & TS & $\mathrm{O}$ & $\mathrm{O}$ & $\mathrm{O}$ & \\
\hline & & \multicolumn{2}{|c|}{ TA } & & & & \\
\hline
\end{tabular}

Legenda:

B:Borobudur; P:Prambanan; AW:Angkor Wat; O: Tanda Cek;

TA:Tidak Ada; A:Ada; TS:Tidak Serupa; S: Serupa

\section{KESIMPULAN}

\subsection{TATA MASSA}

Dari komparasi pada unsur tata massa ditemukan adanya persamaan unsur penataan massa yang sama namun dikembangkan dengan bentukkan yang berbeda. Selain itu juga ditemukanya persamaan pada dualitas pada tatanan masa di mana terdapat tatanan linear dan tatanan memusat. Berikutnya juga ditemukan persamaan dengan adanya pembagian hirarki tiga pada tatanan massa keseluruhan candi yang ditunjukan dengan adanya undakan maupun pagar. Terakhir juga ditemukan persamaan seperti Prambanan di mana candi utama tidak tepat di tengah, sedikit mundur ke belakang.

Tetapi juga ditemukan adanya perbedaan tatanan di mana Angkor Wat memiliki tatanan memanjang dan jawa cenderung simetri. Kemudian juga ditemukan perbedaan skala ruang luar yang berada di dalam tata massa candi. Angkor Wat memiliki area ruang luar yang cenderung lebih luas. Perbedaan berikutnya adalah adanya penggunaan tata massa pagoda intan yang tidak ditemukan di Indonesia. Terakhir yang menjadi pembeda adalah penataan massa dengan elemen lanskap air yang tidak ditemukan di Indonesia.

\subsection{DENAH}

Dari komparasi pada unsur denah ditemukan adanya persamaan dengan teridentifikasinya elemen yang mirip tetapi dikembangkan menjadi lebih rumit, hal tersebut 
muncul pada penggunaan bentuk dasar crusiform dan juga pembagian ruang dalam menjadi 5 ruang.

Tetapi juga ditemukan perbedaan dengan adanya ruang-ruang yang secara fungsi tidak ditemukan di tempat yang satu dan yang lain. Kemudian juga ditemukan perbedaan bentukan ruang luar dan ruang dalam di mana ruang luar dan dalam Angkor Wat sama-sama crusiform. Terakhir ditemukan perbedaan juga dengan adanya selasar yang teridentifikasi sebagai ruang dalam.

\subsection{SOSOK}

Dari komparasi pada unsur sosok ditemukan adanya persamaan dengan teridentifikasinya penggabungan elemen pada sosok candi, ditemukan elemen berundak yang dramatis seperti pada Candi Borobudur tetapi juga ditemukan elemen vertikal candi menara seperti pada Candi Prambanan. Selanjutnya juga ditemukan kemiripan sosok serupa terutama pada siluet candi menara di mana teridentifikasi bentuk kurva pada siluet candi tersebut. Kemudian ditemukanya kemiripan sosok serupa pada candi di mana teridentifikasi penggunaan elemen perulangan secara perspektifis. Terakhir juga ditemukannya kemiripan sosok serupa pada candi di mana teridentifikasi penggunaan pembagian tiga pada seluruh elemen candi.

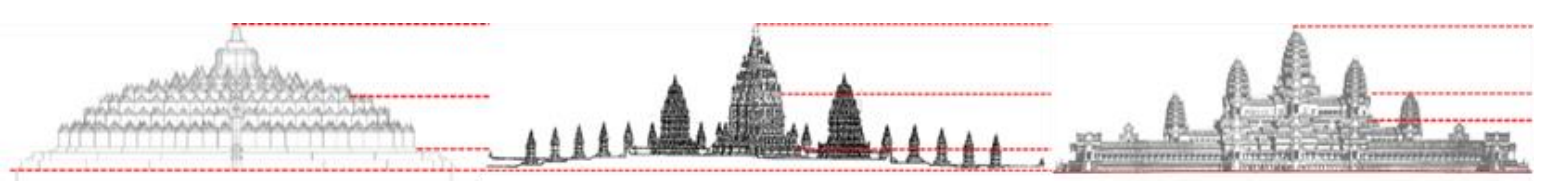

Figur 1. Perbedaan Proporsi Kepala-Badan-Kaki

\subsection{ORNAMEN}

Dari komparasi pada unsur ornamen ditemukan adanya persamaan dengan teridentifikasinya beberapa elemen ornamen yang sama dalam kasifikasi namun memiliki sosok yang berbeda (detail dan ukuran). Selain itu juga ditemukan beberapa ornamen yang memiliki klasifikasi yang sama namun memiliki lokasi yang berbeda pada candi. Terakhir juga ditemukan beberapa ornamen yang memiliki klasifikasi yang sama namun merupakan pengembangan elemen.

\subsection{GLOBAL}

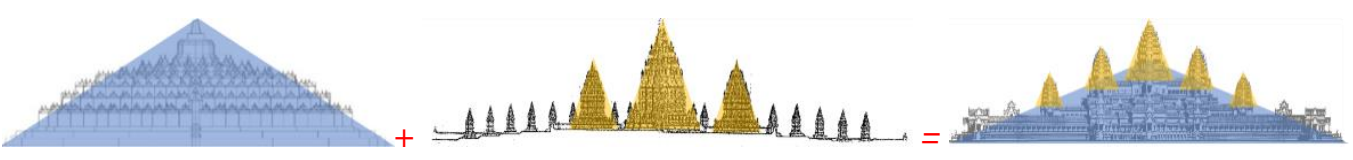

Figur 2. Sintesa Penggabungan Unsur

Dapat disimpulkan secara umum bahwa Angkor Wat terinspirasi Borobudur dan Prambanan. Secara garis besar menunjukan adanya persamaan unsur arsitektur Prambanan dan Borobudur terhadap Angkor Wat. Angkor Wat merupakan sintesa penggabungan unsur (eklektisism) Borobudur dan Prambanan, namun unsur Prambanan lebih kuat (candi beruang, candi menara, candi Hindu). Secara prinsip (tata massa, denah, dan sosok) menunjukkan penggabungan Borobudur dan Prambanan, namun secara ornamen pada pengolahannya menunjukkan ada pengembangan lebih lanjut (didominasi temuan ada tapi tidak serupa). 


\subsection{PEMIKIRAN LANJUTAN (AFTERTHOUGHT)}

Setelah menarik kesimpulan melalui jabaran pada unsur tata massa, denah, sosok, dan ornamen maka dapat ditarik beberapa pemikiran lanjutan berkaitan dengan hasil dari penelitian ini, dijabarkan sebagai berikut:

Dapat didubah walaupun Angkor Wat terinspirasi dari Borobudur dan Prambanan, Unsur Jawa mulai menipis yang ditunjukkan dengan ornamentasi yang semakin berkembang. Perkembangan tersebut juga terjadi pada keseluruhan candi seperti penggunaan skala lebih besar, teknologi yang lebih maju seperti turap (dinding penahan tanah), galeri (selasar beratap) karena faktor alam yang cenderung rata, memiliki teknologi lebih maju dalam bercocok tanam sehingga lebih makmur, serta tuntutan perang.

Candi Jawa seperti Borobudur dan Prambanan pada hakekatnya telah menginspirasi candi Kamboja, hal ini menunjukan eksistensi Kerajaan Mataram Kuno diperhitungkan di Asia Tenggara. Hal ini dibuktikan dengan: Perbedaan proporsi yang dimungkinkan karena teknologi high rise building seperti Prambanan yang lebih maju. Teknik pertukangan Jawa Klasik Tengah lebih maju karena material yang lebih pejal dan teknik pengangkutan yang lebih apik.

Dengan fenomena eksistensi Jawa Klasik Tengah di Asia Tenggara yang terbukti dengan mampunya candi Jawa menginspirasi sampai ke Kamboja, alangkah baiknya para arsitek sekarang ini mengimplementasikan unsur arsitektur lokal Indonesia seperti yang terdapat pada arsitektur candi.

\section{DAFTAR PUSTAKA}

\section{Jurnal}

Prajudi, Rahadhian, H, 2008, The Architectural Development of Candi in Java, Indonesia, Journal of South East Asia JSEA vol 11, NUS- SingaporeJournal of South East Asia JSEA vol 11, NUSSingapore

Makalah Ilmiah

Prajudi, Rahadhian, H, 2014, Kajian Unsur Arsitektonik Transformatif dalam Arsitektur Rumah Tradisional di Indonesia -Puslitbangkim, Lombok

Prajudi, Rahadhian, H 2015, Arsitektur Candi sebagai representasi kuatnya tradisi membangun di Indonesia, Kolokium Dies Natalis Fakutas Teknik, Unpar, Bandung.

Santiko, Hariani (1995), Seni Bangunan Sakral Masa Hindu-Buda di Indonesia Analisis Arsitektur dan Makna Simbolik, Pidato Pengukuhan Guru Besar Madya Tetap pada Fakultas Sastra Universitas Indonesia, Depok.

\section{Buku}

Acharya, Prasanna K, (1979), Hindu Architecture in India and A broad. New Delhi: Oriental Books Reprint Corporation.

Albanese, Marilia (2006), Angkor Splendors of Khmer Civilization, Italy, White Star S.r.j

Antoniades, Anthony C. (1992), Poetics of Architecture, Theory of Design, New York, Van Nostrand Reinhold.

Atmadi, Parmono (1979), Some Architectural Design Principles of Temples in Java Gadjah Mada University.

Bekaert, Jacques (2002), Bas-Reliefs: Life at the Angkor Period, Bangkok, Asia Horizons Book

Borobudur, Balai Konservasi (2013), Proceeding $6^{\text {th }}$ International Experts Meeting on Borobudur 2013, Magelang, Balai Konservasi Borobudur

Borobudur, Balai Konservasi (2014), Merekam Jejak Masa Lalu Cagar Budaya Dalam Perspektif 3D, Magelang, Balai Konservasi Borobudur 
Borobudur, Balai Konservasi (2015), Buku Hasil Kajian Bali Konservasi Borobudur: Tahun Kajian 2015, Magelang, Balai Konservasi Borobudur

Borobudur, Balai Konservasi (2016), Kearsitekturan Candi Borobudur, Magelang, Balai Konservasi Borobudur

Borobudur, Balai Konservasi (2016), Selayang Pandang: Candi Borobudur, Candi Mendut, Candi Pawon, Magelang, Balai Konservasi Borobudur

Budihardjo, Eko, ed (1996), Jati Diri Arsitektur Indonesia, Bandung, Penerbit PT Alumni.

Chihara, Daigoro (1996), Hindu-Buddhist Architecture in Southeast Asia, New York, E.J. Brill.

Degroot, dan Tim (2013), Magical Prambanan, Yogyakarta, BAB Publishing Indonesia

Dumarcay, Jaques (2007), Candi Sewu dan Arsitektur Bangunan Agama Buddha di Jawa Tengah, Jakarta, KPG

Eliade, Mircea (1969), Image and Symbols : Studies in Religious Symbolism, USA, Harvill Press.

Freeman, Michael (2013), Books Guides: Abcient Angkor, Thailand, River Books

Frampton, K., Foster, H, Editor, 1983, Towards a Critical Regionalism: Six Points for an Architecture of Resistance", in The Anti-Aesthetic: Essays on Postmodern Culture. edited by Hal Foster, Bay Press, Port Townsen

Giteau, Madeleine (1997), History of Angkor, Paris, Kailash Editions

Jacques, Claude (1999), Angkor, Bonner Cologne, Konemann

Jacques, Claude (2007), The Khmer Empire: Cities and Sanctuaries from the 5th to 13th Century, Thailand, River Books

Lall, Vikrem (2014), Architecture of The Buddhist World: The Golden Lands, JF Publishing, Malaysia Leupen, Bernard, etc (1997), Design and Analysis, New York, Van Noestrand Reinhold

Mangunwijaya, Y. B. (2009), Wastu Citra, Jakarta, Gramedia Pustaka Utama.

Ortner, Jon (2002), Angkor, New York, Abbeville Press Publishers

Petrotchenko, Michel (2014), Focusing on the Angkor Temples The Guidebook Third Edition, Thailand, Amarin Printing and Publishing PCL

Philippe, Bernard, G (2002), Indocina Persilangan Kebudayaan, Jakarta, Kepustakaan Populer Gramedia

Prijotomo, Josef (1988), Ideas and Form of Javanese Architecture, Yogyakarta, Gadjah Mada University Press.

Purwasito, Andrik (2002), Imajeri India: Studi Tanda dalam Wacana, Surakarta, Yayasan Pustaka Cakra.

Rawson, Philip (1967), The Art of Southeast Asia, World of Art, Singapore

Stierlin, Henri (1971), Angkor, Nederland, Meulenhoff Nederland N.V.

Sastri, Nilakantha (1976), A History of South India, OUP India

Schreitmueller, Karen (2002), India, Baedeker

Snodgrass, Adrian (1984), The Symbolism of The Stupa: Studies on Southeast Asia, New York, SEAP

Soekmono, R. (1973), Pengantar Sejarah Kebudayaan Indonesia 2, Yogyakarta, Penerbit Kanisius

Tjahjono, Gunawan, editor (2009), Sejarah Kebudayaan Indonesia, Arsitektur, Jakarta, Raja Grafindo Perkasa.

Tim penulis AboutAsia Travel (2015), The Angkor Guidebook, Siem Reap, Monument Books

\section{Tesis/Disertasi}

Prajudi, Rahadhian, H ,1999, Kajian Tipo-Morfologi Arsitektur Candi di Jawa, Thesis, Arsitektur Institut Teknologi Bandung, Bandung, 2011, Representasi Candi dalam Dinamika Arsitektur di Indonesia, Disertasi Doktor, Unpar, Bandung

Soekmono R., 1974, Candi, Fungsi dan Pengertiannya, Disertasi Doktor, Universitas Indonesia, Jakarta Skripsi

Citra, Irwan, 2015, Perkembangan Tatanan Massa dan Ruang Arsitektur Candi di Jawa (Dari Masa Klasik Tua, Klasik Tengah, dan Kilasik Muda), Skripsi Universitas Katolik Parahyangan, Bandung 
Halim, Andre, 2016, Makna Ornamen pada Bangunan Candi Hindu dan Budha di Pulau Jawa (Era Klasik Tua - Klasik Tengah - Klasik Muda), Skripsi Universitas Katolik Parahyangan, Bandung

Kartawidjaja, Adrian, 2015, Pengaruh Unsur-Unsur Desain Arsitektur Pagoda Cina Terhadap Candi Masa Singosari-Majapahit. Objek Studi: Candi Kidal, Jago, Jawi, Skripsi Universitas Katolik Parahyangan, Bandung

Kurnadi, Marco, 2002, Estetika pada Arsitektur Candi Jawa, Skripsi Universitas Katolik Parahyangan, Bandung

Leewan, 2015, Penerapan Konsep Mahayana pada Arsitektur Candi Era Mataram Kuno. Objek Studi: Candi Borobudur, Mendut, Pawon, Kalasan, dan Sewu, Skripsi Universitas Katolik Parahyangan, Bandung

Limanjaya, Marvin, 2016, Tektonika Arsitektur Candi di Jawa Ditinjau dari Bentuk, Material, dan Teknologi, Skripsi Universitas Katolik Parahyangan, Bandung

Pradipta, Martin, 2016, Ciri Budaya Megalitik Pada Arsitektur Candi di Pulau Jawa, Skripsi Universitas Katolik Parahyangan, Bandung

Ramos, 2016, Dinamika Penerapan Proporsi Pada Arsitektur Candi Tipe Menara Era Klasik TuaTengah-Muda di Pulau Jawa, Skripsi Universitas Katolik Parahyangan, Bandung 